\title{
Yaşlanan Nüfusa Çözüm Önerisi Olarak Aktif Yaşlanma Yaklaşımı: Eleştiriler ve Olası Endeks için Türkiye Önerileri*
}

\section{The Active Aging Approach as a Solution to the Aging Population: Criticisms and Suggestions for a Possible Index for Turkey}

\section{Seyran Gürsoy Çuhadar' ${ }^{1}$ (])}

Öz

Yaşlanma olgu olarak insanlık tarihi kadar eski olsa da, toplumların yaşlanmasının tarihi yenidir. Tüm demografik göstergeler, Türkiye'nin demografik dönüşümün son aşamasına geldiğini ve hızla yaşlanan nüfusuyla artık yaşlı ülke sınıflamasına dâhil olduğunu göstermektedir. Kuşkusuz toplumların yaşlanıyor olması Türkiye'ye özgü bir olgu değildir. Türkiye'ye özgü olan, Avrupa'da yüzyılı bulan demografik geçişin, Türkiye'de 27 yıl gibi çok daha kısa sürede gerçekleşecek olması ve bu bağlamda Türkiye'nin yaşlanma kaynaklı sorunlarla yeterince zenginleşemeden yüzleşmek zorunda kalacak olmasıdır. Bu noktada Dünya Sağıık Örgütü ve Birleşmiş Milletler gibi uluslararası kuruluşların, sağlıklı ve aktif yaşlanan bir nüfusu teşvik etmek için çözüm önerileri sundukları bilinmektedir. Aktif yaşlanma yaklaşımı bu önerilerin başında gelmektedir. Aktif yaşlanma, insanların yaşlandıkça hayat kalitelerini iyileştirmek amacıyla bu kişilere yönelik sağlık, katılım ve güvenlik konusundaki firsatların yükseltilme süreci olarak tanımlanmaktadır. Aktif yaşlanma, toplumlar için hedef olarak gösterilmiş ve bu kapsamda aktif yaşlanma endeksi oluşturulmuştur. Aktif yaşlanma endeksi ile yaşlı bireylerin bağımsız yaşama, ücretli istihdam ve sosyal etkinliklere katılım düzeyleri ile aktif olarak yaşlanma potansiyelleri ölçülmektedir. Endeks aynı zamanda ülke kıyaslamaları yaparak, politika yapıcılara geliştirilebilir öncelikli alanları da göstermektedir. Buradan hareketle çalışma, aktif yaşlanma bağlamında Türkiye için öneriler oluşturmayı hedeflemektedir. Bu çerçevede Türkiye'nin öncelikle yapması gereken, çok hızlı yaşlanan bir ülke olduğu gibi bugün itibariyle de zaten yaşlı bir ülke olduğu gerçeğini kabul etmesi ve gerekli önlemleri alırken, ülkenin sosyo-ekonomik, kültürel ve toplumsal yapısını da göz önüne alan aktif yaşlanma endeksi benzeri araçlarla elde edilen verilerden hareket etmesidir. Türkiye'nin toplumsal yapısını temel alarak geliştirilen endekslerin, benzer çalışmalar için daha sağlıklı

* Bu makale, yazarın 2019 yılında tamamlamış olduğu “Türkiye'de Demografik Dönüşüm ve Aktif Yaşlanma İlişkisi: Kocaeli Örneği" başlıklı doktora tezinden türetilmiştir.

1 Sorumlu Yazar: Seyran Gürsoy Çuhadar (Arş. Gör. Dr.), Kocaeli Üniversitesi, İktisadi ve İdari Bilimler Fakültesi, Çalışma Ekonomisi ve Endüstri İlişkileri Bölümü, Kocaeli, Türkiye. E-posta: seyran.gursoy@kocaeli.edu.tr ORCID: 0000-00017443-4184

Attf: Gursoy-Cuhadar, S. (2020). Yaşlanan nüfusa çözüm önerisi olarak aktif yaşlanma yaklaşımı: eleştiriler ve olası endeks için Türkiye önerileri. Sosyal Siyaset Konferansları Dergisi, 79, 361-397. https://doi.org/10.26650/jspc.2020.79.0004 
sonuçlar vereceğini söylemek mümkündür. Bununla birlikte yaşlılığın çok boyutlu bir olgu olduğu bilinciyle, yaşılıı çalışmaları artırılmalı ve veriye dayalı bütünleşik sosyal politikalar üretilmelidir.

\title{
Anahtar Kelimeler
}

Yaşlanma, Aktif Yaşlanma, Demografik Dönüşüm, Aktif Yaşlanma Endeksi, Yaşlanan Toplumlar

\begin{abstract}
Although aging is as old as human history, the aging of whole societies is new. All demographic indicators show that Turkey, with its rapidly aging population, has reached the last stage of demographic transformation and can be classified as an old-age country. Aging issues do not matter only in Turkey; what is distinct in the Turkish context is the fact that it started facing its aging population problem 27 years ago, while Europe has already been experiencing the process of demographic transition for about a century. Thus, Turkey must face the problems resulting from its rapidly aging population without reaching an adequate level of prosperity and wealth. The World Health Organization and the United Nations have offered solutions to encourage and sustain a healthy and active aging population. The active aging approach is one of the leading policy suggestions. Active aging is defined as the process of increasing opportunities for health, participation, and security in order to improve the quality of life as people age. Active aging is an identified target for societies and an Active Ageing Index has been created in this context. Through the Active Ageing Index, elderly individuals can potentially sustain an independent living, engage in paid work, and participate in social activities; and then it is possible to measure the extent of active aging undertaken. By comparing other country's examples, the Active Ageing Index also offers a framework for improving policy spheres noting high priorities for policymakers. Thus, the study aims to offer recommendations for Turkey in the context of active aging. Given Turkey's rapidly aging population, the main priorities should focus on developing policy solutions and initiating measures that take into account the data produced through policy approaches, such as the Active Ageing Index, informed by the socioeconomic, cultural, and social structures of the country. It is possible to suggest that indexes developed by taking into account the social structure of Turkey will produce more viable results for similar studies. In addition, with the awareness that aging is a multi-dimensional phenomenon, more studies on aging are needed and integrated social policies relying on data should be initiated and developed.
\end{abstract}

\section{Keywords}

Aging, Active Aging, Demographic Transformation, Active Ageing Index, Aging Societies 


\section{Extended Summary}

Demographic transformation theory, which states that the demographics of countries will move from high to low fertility and mortality rates, claims that all societies will inevitably go through these stages. According to this theory, demographic transition will take place first in Europe and North America, then in Asia and Latin America, and most recently, in Sub-Saharan African countries. Indeed, throughout the 20th century, Continental Europe has witnessed the transformation of its aging communities, and today, Turkey is rapidly going through the final stage of its demographic transition. Similar to Europe, the demographic transformation process of Turkey is composed of falling birth rates, a decline in the mortality rate, extended life expectancy, and differing migration processes. According to the most recent data (2019), fertility rates in Turkey (1.99) have fallen below the replacement level of the population (2.1), life expectancy at birth is prolonged (78.3), and especially with the adopted "open door" immigration policy, Turkey has become a migration receiving society. All these factors significantly affect the structure of Turkey's population. In this sense, with an aging population of more than 7.5 million, Turkey seems to be classified as an elderly country.

If societies are prepared enough for the aging process (for example, having a certain level of wealth directed toward social welfare), social aging may not be a problem. Unfortunately, Turkey is facing an aging population problem without raising its level of social welfare. There are many questions that Turkey needs to answer, such as how individuals stay independent and active as they age, how to strengthen their health and social protection systems, how to improve the quality of life of individuals in prolonged life, and how to maintain a state-family balance in elderly care. This situation is, of course, not only peculiar to. In particular, European countries, which completed this demographic transition earlier than Turkey, can be a role model for Turkey in this process.

However, international organizations such as the World Health Organization) and the United Nations are also developing policy recommendations advocating that societies take precautions for their aging populations. The active aging approach is one such policy recommendation. The most comprehensive and most commonly used definition of active aging by the WHO is the process of increasing the opportunities for health, as well as the participation and safety offered to individuals in order to improve the quality of life as they age. Active 
aging adopts a rights-based approach, giving people the right to equal opportunities in all areas as they age. While helping people realize their potential for physical, social and cognitive wellbeing throughout their lives, the active aging approach emphasizes the provision of adequate protection, safety, and care when needed. In order to achieve this goal, an Active Ageing Index was created, in which the current situation for aging individuals is determined, the potential of the elderly to engage in activities of active aging is measured, and social policies are developed within this scope. The Index is defined as a tool for policymakers to develop data-based strategies to produce solutions to problems arising from the aging of the population. The Index aims to reveal the priority areas to a country by making comparisons of its components with other countries. The Active Ageing Index consists of four main parameters and sub-components of these parameters, with categories of Employment, Participation in Society, Independent Healthy and Secure Living, Capacity, and Enabling Environment for Active Ageing. The first three parameters refer to various activities involving older individuals, as well as real experiences that reflect independent, autonomous and safe living experiences; while the last parameter emphasizes the potential for active aging based on the individual's own characteristics, as well as environmental factors that can make active aging easier or more difficult. Hence, the Active Ageing Index is advisable for use to analyze the current situation in Turkey for the elderly. However, at this point in Turkey, specific issues should not be ignored. Some revisions to the parameters of the Active Ageing Index are recommended, which has many features that differ from European countries' experience in a socioeconomic, cultural, and historical sense. As a result, studies that center on aging should be expanded. Longitudinal studies, especially on old age, should be conducted and policies should be created based on the resulting data. 


\section{Yaşlanan Nüfusa Çözüm Önerisi Olarak Aktif Yaşlanma Yaklaşımı: Eleştiriler ve Olası Endeks için Türkiye Önerileri}

Nüfus ve yaşlanma ilişkisinin tarandığ literatürde, sıklıkla nüfusun yaşlanma oranının iki katına çıkması için (\% 7'den \% 14'e ) gereken süre baz alınarak ülke kıyaslamasının yapıldığı görülür. Başta Fransa olmak üzere gelişmiş ülkelerin nüfuslarının yaşlanması sürecinde yaş yapısındaki değişikliklere uyum sağlamak için yeterince vakitlerinin olduğu (Fransa için bu süre tam 114 yıldır), buna karşılık Türkiye gibi gelişmekte olan ülkelerde ise bu sürecin çok hızlı gerçekleştiği ya da gerçekleşeceği ifade edilir. Demografik dönüşüm olarak tanımlanan bu süreçte, Türkiye için bu süre 27 yıl olup, 2030 yılında sürecin tamamlanacağı öngörülmektedir. Avrupa' da genellikle yüzyılı bulan demografik geçişin, Türkiye için bu kadar kısa sürede tamamlanacak olması, Türkiye'nin nüfusun yaşlanmasından kaynaklanan sorunlarla baş etmede yetersiz ve hazırlıksız kalabileceği ihtimalini doğurmaktadır. Nitekim 2019 verileri, Türkiye'de 65 yaş üstü nüfusun toplam nüfusa oranının $\% 9,1$ olduğunu ve dolayısıyla Türkiye'de yaşlı sayısının 7,5 milyonu aştığını göstermektedir. Kimi Avrupa ülkesinin toplam nüfusundan fazla olan bu sayı, üzerinde ciddi anlamda düşünülüp politika geliştirilmesini gerektirmektedir.

Bu bağlamda, Dünya Sağlık Örgütü (DSÖ)'nün toplumların yaşlanmasıyla birlikte meydana gelecek sorunlara çözüm önerisi olarak aktif yaşlanma yaklaşımını ortaya koydukları bilinmektedir. Yaşlanmaya hem makro hem de mikro bir bakış açısı sunan yaklaşım, aktif yaşlanma endeksi oluşturarak, aktif yaşlanmaya ait ana parametreler ve alt bileşenler üzerinden ülkeleri kıyaslamakta (daha çok AB ülkelerini) ve ülkelere geliştirilebilir yönlerinin neler olduğunu, daha iyi ülke örnekleriyle birlikte sunmaktadır. Kuşkusuz böyle bir endeks çalışması, Türkiye için de politika belirleme konusunda önem arz edecektir. Buradan hareketle çalışma öncelikle, aktif yaşlanma yaklaşımını ve bu bağlamda oluşturulan aktif yaşlanma endeksini ayrıntılarıyla sunarak, Türkiye için olası bir endeks çalışmasında önemli noktaları ortaya koymayı amaçlamaktadır. $\mathrm{Bu}$ kapsamda öncelikle, dünyadaki demografik dönüşüm üzerinden Türkiye’ye kapı aralanacak, sonrasında da toplumların yaşlanıyor olmasından kaynaklanan sorunlara çözüm önerisi olarak ortaya konan aktif yaşlanma yaklaşımı tüm ayrıntılarıyla ortaya konmaya çalışılacaktır. Bu noktada çalışmanın odağını, aktif yaşlanma endeksi, endekse ait ana parametreler ve alt bileşenler oluşturacaktır. Çalışmanın son bölümünde yaklaşıma ait eleştirilere ve Türkiye için olası bir endeks çalışması için kimi önerilere yer verilecektir. 


\section{Nüfus Piramidinden Nüfus Sütununa}

Demografiye ilişkin literatüre bakıldığında, nüfus piramidinin sıklıkla karşılaşılan bir kavram olduğu görülmektedir. Kavram, bir ülke ya da bölgenin yaş gruplarına ve cinsiyete göre dağılımını gösteren şekli ifade etmektedir. Piramit, şeklinden hareketle genç nüfusun şişkinliğini buna karş1lık yaşlı nüfusun azlığını göstermektedir. Ancak günümüz istatistikleri ve nüfus projeksiyonları bu seyrin değiştiğini, piramit olan şeklin giderek sütuna evrildiğini göstermektedir. Hızla yaygınlaşan teknolojik gelişmelerle, artan sosyal refahın bir sonucu olarak sağlık ve bakım hizmetlerinin gelişmesi bu durumun en önemli nedenleri olarak gösterilmektedir. Öte yandan modernitenin sosyal yansıması olarak özellikle gelişmiş ülkelerde görülen doğum oranlarındaki düşüş (doğurganlık oranlarındaki azalma) de yaşlı nüfusun artışındaki bir diğer neden olarak karşımıza çıkmaktadır (UN, 2016: 34; Uyanık, 2017: 73). Bu noktada her ne kadar doğum ve ölüm oranları kadar belirleyici ve ölçülebilir olmasa da göç olgusunun da nüfusun değişmesinde etkili olduğu ifade edilmelidir (UN, 2019: 32). Bununla birlikte yaşlanmanın, her bölgede homojen olarak aynı oranlarla arttığını söylemek doğru değildir. Nitekim Grafik 2'de de görüldüğü üzere Birleşmiş Milletler'in nüfus projeksiyonlarında Sahra-altı Afrika'da nüfus artışının devam edeceği öngörülmektedir. 


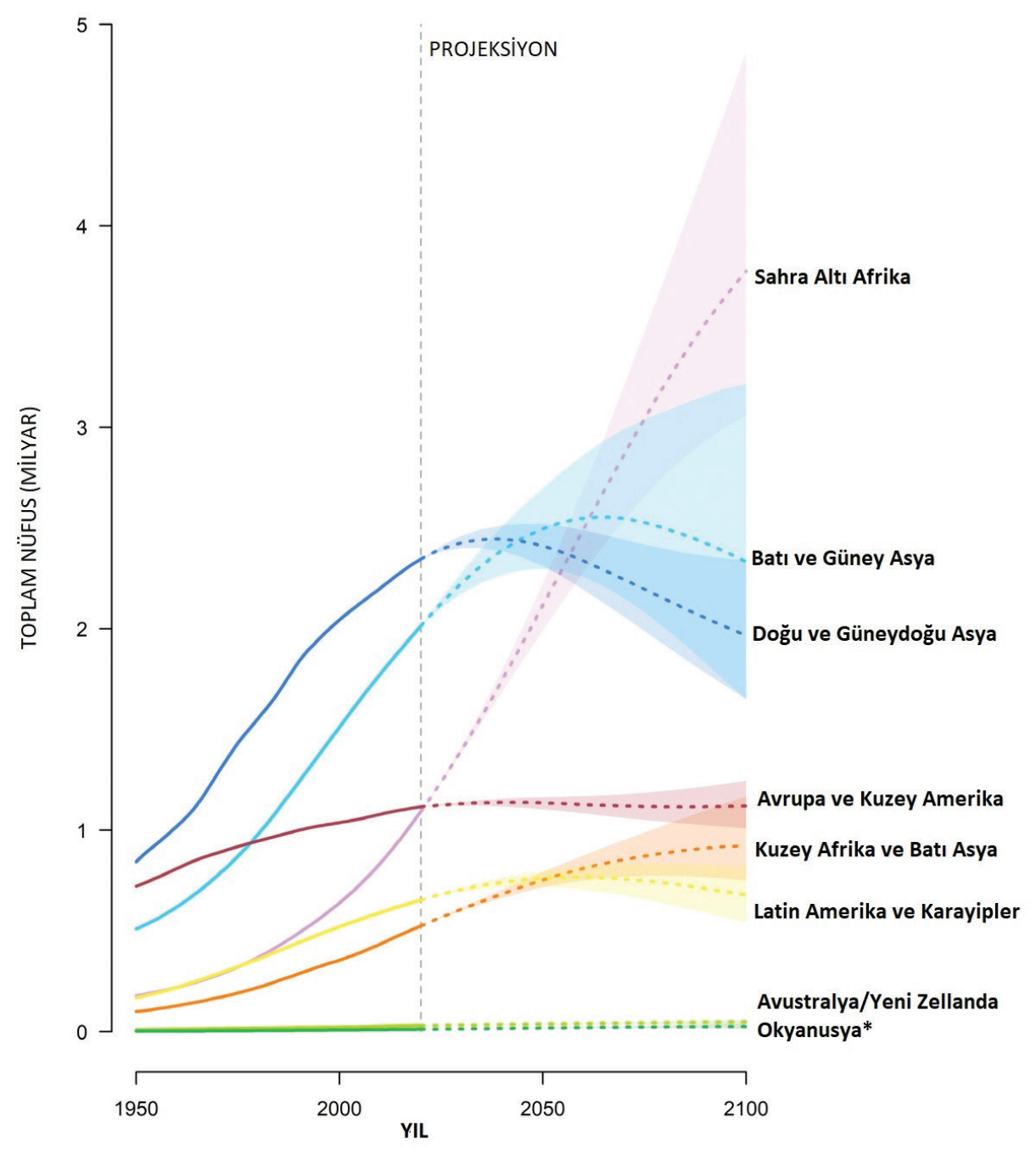

Grafik 1. 1950-2020 ve yüzde 95 tahmin aralıklı orta değişkenli nüfus projeksiyonu, 2020-2100 Kaynak: (UN, 2019: 7)

Ancak her ne kadar yaşlanma, öncelikle gelişmiş ülkelerin son yüzyılda yüzleştikleri sorun alanı gibi görünse de, gelişmekte olan ülkelerin de son birkaç on yılda yaşlanma sürecine girdiğine tanık olunmaktadır (Kinsella ve Phillips, 2005: 5; Mendes, 2013: 174). Nitekim Kinsella ve He'nin (2009: 2) hazırladıkları Uluslararası Nüfus Raporu dünyada yaşlı nüfusun Avrupa ve Kuzey Amerika'nın endüstrileşmiş bölgelerine yayıldığını, bununla birlikte gelişmekte olan ülkelerin yaşlı nüfus oranının gelişmiş ülkelere göre daha hızlı arttığını göstermektedir. Tablo 1, bu savın desteklenmesi bakımından önemlidir. 
Tablo 1

Bazı Ülkelerde ve Türkiye'de Yașlanma Hızı *

\begin{tabular}{lcccc}
\hline Ülkeler & $\begin{array}{c}\text { \%7 Oranına } \\
\text { Ulaşılan Yll }\end{array}$ & $\begin{array}{c}\text { \%14 Oranına } \\
\text { Ulaşılan Yll }\end{array}$ & $\begin{array}{c}\text { Geçiş Süresi } \\
\text { (YIl) }\end{array}$ \\
\hline \multirow{3}{*}{ Gelişmiş ülkeler } & Fransa & 1865 & 1980 & 115 \\
& İsveç & 1890 & 1975 & 85 \\
& ABD & 1945 & 2013 & 69 \\
& İngiltere & 1930 & 1975 & 45 \\
Gelişmekte & Azerbaycan & 2004 & 2037 & 33 \\
olan ülkeler & Brezilya & 2011 & 2032 & 21 \\
& Güney Kore & 2000 & 2018 & 19 \\
& Türkiye** & 2012 & 2039 & 27 \\
\hline
\end{tabular}

*65 yaş ve üstü nüfusun 0-64 yaş arasındaki nüfusa oranının \%7'den \%14'e geçiş süresi

**Türkiye, TÜİK'in nüfus projeksiyonundan hesaplanmıştır.

Kaynak: (Kinsella and Gist, 1995: 5)

Yukarıdaki tablodan de görüleceği üzere gelişmiş bir ülke olan Fransa' da yaşlı nüfus oranının \% 7'den \% 14'e yükselmesi 115 yıl gerektirirken, gelişmekte olan ülkelerden Azerbaycan'da aynı oranda artış için yalnızca 19 yıl geçmesi yetecektir. Yine benzer şekilde Avrupa'nın neredeyse yüzyılı bulan yaşlanma sürecine Türkiye'nin 27 yılda ulaşacağı öngörülmektedir. Bu durum demografik dönüşüm sürecinin Türkiye gibi ülkelerde ertelenmiş ve daha kısa sürede gerçekleşen/gerçekleşecek bir süreç olduğunu göstermektedir (TÜSİAD, 1999: 6, Koç vd, 2010: 5). Demografik dönüşümün bu denli hızlı gerçeklemiş/gerçekleşecek olması ise ülkelerin nüfuslarının yaşlanmasının beraberinde getireceği sorunlarla başa çıkmada hazırlıksız olabileceklerini gösterebilmektedir. Nitekim yaşlıların kaç yıl daha sağlıklı yaşayacakları, yüzleşmek zorunda kalacakları kronik rahatsızlıkların neler olacağı, kaçının çalışmaya devam edeceği ya da geri kalan hayatlarını rahatlıkla idame ettirip ettiremeyecek gelirleri olup olmayacağ 1 , sağlık giderlerini karşılayıp karşılayamayacakları ya da kimseye bağımlı olmadan yaşayıp yaşayamayacakları gibi sorular nüfusların yaşlanmasıyla birlikte cevaplanması gereken soruların yalnızca birkaçıdır. Kuşkusuz bu sorulara yanıt bulmak için öncelikle yaşlılığ değerlendirmek gerekiyor. Yaşlılığın çok boyutlu olduğunu ve yukarıda sorulan soruların cevapları için hem bireye hem de devlete birtakım yükümlülükler getirdiğini söylemek mümkündür. Aktif yaşlanma yaklaşımı işte tam da bu yükümlülüklerin birleşiminde yer almaktadır. 


\section{Aktif Yaşlanma Yaklaşımı}

Toplumların yaşlanması ile birlikte, yaşlandıkça bireylerin bağımsız ve aktif nasıl kalacakları, sağlı ve sosyal koruma sistemlerinin nasıl güçlendirileceği, uzayan ömürde bireylerin yaşam kalitelerinin nasıl artırılacağı, yaşlı bakımında devlet-aile dengesinin nasıl korunacağı gibi yasa yapıcıların cevaplamaları gereken pek çok soru meydana gelmiştir. Bu kapsamda Avrupa Komisyonu'nun 1990'ların başlarında, ulusal politikaların yaşlanma üzerindeki etkisini incelemek için bir "gözlemevi” kurmasıyla birlikte, yaşlanma bir Avrupa politikası sorunu olarak kabul edilir. Akabinde 1993 yılının Avrupa Yaşlılar Yı11, 1999 yılının ise BM'ce Yaşlı Yılı olarak kabul edilmesi konunun öneminin altının çizilmesi bakımından önem arz etmektedir. Bu kapsamda Avrupa Komisyonu (1999: 5) tarafindan ortaya konan “Towards a Europe for All Ages (Her Yaş İçin Avrupa'ya Doğru)" adlı politika belgesi ile çalışma çağındaki nüfusun azalması, emekli aylıkları sistemleri ve kamu maliyesi harcamaları, artan bakım ihtiyacı ve yaşı ı bireylerin kaynakları ve riskleri arasındaki çeşitlilik başlıklı dört zorluk belirlenmiştir. Avrupa'daki istihdam oranını artırmak (yaşam boyu öğrenmeyi teşvik ederek, esnek çalışma düzenlemeleri ve istihdam teşviklerini artırarak), sosyal koruma politikalarını iyileştirmek, erken emeklilik eğilimlerini tersine çevirmek, sağlık politikaları ve yaşlı bakımı ile ilgili araştırmaları desteklemek ve işyerinde ayrımcılığa ve sosyal dışlanmaya karşı politikalar geliştirmek bu zorluklara karşıllk oluşturulan çözüm önerileridir (Foster ve Walker, 2015: 86). Benzer şekilde DSÖ (2002), hükümetlere, uluslararası örgütlere ve sivil topluma yaşlı yurttaşların sağlığını, katılımını ve güvenliğini artıran "aktif yaşlanma" politikaları ve programları yürürlüğe koymalarını önerdiği görülmektedir.

Aktif yaşlanmaya ait hemen hemen bütün çalışmalarda kullanılan en kapsamlı tanım, DSÖ tarafından yapılmıştır. Bu tanıma göre aktif yaşlanma, insanların yaşlandıkça hayat kalitelerini iyileştirmek amacıyla bu kişilere yönelik sağlık, katılım ve güvenlik konusundaki firsatların yükseltilme sürecidir (WHO, 2002: 12). Yaklaşım, yaşlı bireylerin topluma ve politik yaşama dahil olurken sağlıklı kalmalarına (sağlık ve sosyal giderlerin düşürülmesi) ve istihdam edilebilirliklerinin artırılmasına (emeklilik giderlerinin düşürülmesi) yönelik haklarına ulaşmalarına yardımcı olmaya yöneliktir (Foster ve Walker, 2015: 84). Bu bağlamda yaşlıların sağlıklarını, katılımlarını ve güvencelerini iyileştirmeye yönelik olarak hükümetlerin, uluslararası örgütlerin ve sivil toplumun "aktif yaşlanma" politika ve programları yaşama geçirildiğinde, yaşlıların yaşamlarını daha iyi sürdürebilecekleri öngörülmektedir (WHO, 2002). 
Aktif yaşlanmanın kökenini 1960 başlarında ABD’ de bireylerin yaşlandıkça toplumla bağlarının kopmasına yönelik teze karşılık geliştirilen Geri Çekilme/ Aktivite kuramında (Disengagement/Activity Theory) bulmak mümkündür (Foster ve Walker, 2015: 84). 1961 yılında Cumming ve Henry tarafindan geliştirilen aktivite kuramına göre bireylerin yaşlandıkça kaçınılmaz olarak aktiviteleri ya da rolleri azalmaktadır (Schroots, 1996: 744; Collins, 2014: 1; Foster ve Walker, 2015: 84; Manuel de Sao Jose vd., 2017: 49). Başarılı yaşlanma modelinde olduğu gibi aktif yaşlanma yaklaşımının da temelinde özellikle emeklilik döneminin başlamasıyla birlikte kişilerin pasifleştiği ve pasifliğin, arzu edilmeyen ve kişileri toplumdan soyutlayan, işe yaramazlık duygusunu körükleyen olumsuz bir gelişme olduğu düşüncesi bulunmaktadır. Aktivite kuramına göre yaşlılık döneminin, en mutsuz yaşam safhasına dönüşmemesi için emeklilik sonrası yaşamda da bireyin aktif kalması gerekmektedir. Çünkü mutlu ve huzurlu yaşl1lık döneminin tek koşulu aktif kalmaktan geçmektedir (Tufan, 2016: 147). Bu bağlamda aktif yaşlanma yaklaşımı, stratejik planlamasını, yaşlı insanların pasif hedefler olduğunu var sayan "ihtiyaca dayalı" bir yaklaşımdan, insanların yaşlandıkça hayatın her alanında firsat eşitliği ve muamele hakkını tanıyan "hak temelli” bir yaklaşıma kaydırmaktadır (WHO, 2002: 13). Bununla birlikte yaşlı insanların potansiyelinden faydalanmaya dayalı bir politika söylemi olarak aktif yaşlanma, sosyal yatırım yaklaşımı ile uyumludur. Bilindiği üzere sosyal yatırım, ileriye yönelik sosyal politikaların etkinleştirilmesinin yüksek ekonomik ve sosyal getirileri doğurabileceği fikrini odağına almaktadır.

Bilimsel açıdan aktif yaşlanma, sağlıklı, başarılı veya üretken yaşlanmanın güçlü bir şekilde ilişkili olduğu şemsiye bir kavram olarak düşünülebilir (Fernandez-Ballesteros vd., 2013: 2). Nitekim Rowe ve Kahn'nın (1997: 433434) başarılı yaşlanma modelini oluşturan üç bileşene (1-Hastalık ve engellilik durumlarından kaçınma, 2- Hayata bağlanma, 3- Yüksek bilişsel ve fiziksel işlev) ya da benzer şekilde insanların kendi sağlıklarına, ailelerine ve yaşlandıkça topluma katkıda bulunmanın çeşitli yollarını işaret eden üretken yaşlanmaya (Buttler, 2002: 323) bakıldığında, ortak noktanın yaşlılığın kazanımlara ve potansiyellere sahip olabildiği fikrinin olduğunu görmek mümkündür (Foster ve Walker, 2015: 84). Bu ortak nokta üzerinden aktif yaşlanmanın da, yaşlanmaya adaptasyonu teşvik etmek için psikolojik, psiko-sosyal ve sağlık faktörlerin önemini yansıtan bir kavram olarak karşımıza çıktığını söylemek mümkündür. Bu kapsamda aktif kelimesi de yalnızca fiziksel olarak aktif olma ya da 
çalışmaya devam etme yeteneği değil, toplumsal, ekonomik, kültürel ve manevi konulara sürekli katılım anlamına gelmektedir (Mendes, 2013: 174).

Öte yandan aktif yaşlanma, insanların yaşam boyunca fiziksel, sosyal ve zihinsel iyi olma potansiyellerini gerçekleştirmelerine ve ihtiyaç, istek ve kapasitelerine göre topluma katılmalarına yardımcı olurken, onlara ihtiyaç duyduklarında yeterli koruma, güvenlik ve bakım sağlamaktadır (WHO, 2002: 12). Bununla birlikte aktif yaşlanma yaklaşımının, yaşlıların insan haklarının tanınmasına ve BM'nin bağımsızlık, katılım, onur, bakım ve kendini gerçekleştirme prensiplerini de baz aldığg ifade edilmelidir. Bir diğer ifadeyle aktif yaşlanma sürecini, toplumdaki ekonomik, sosyal, bireysel, davranışsal, sosyal ve çevresel koşullar belirlemektedir (Grafik 3).

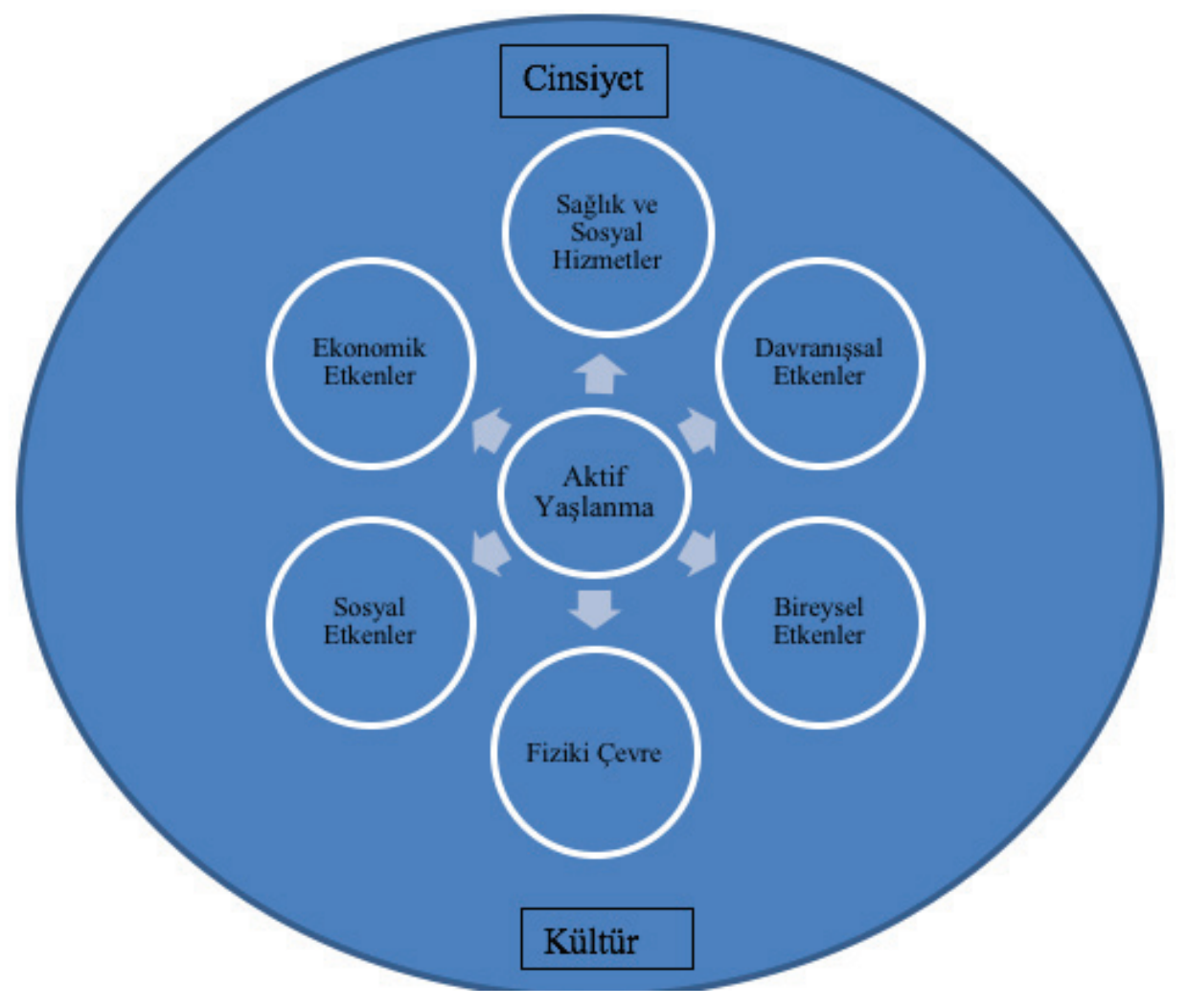

Grafik 2. Aktif Yaşlanma Etkenleri

Kaynak: (WHO, 2002: 19) 
$\mathrm{Bu}$ etkenler içinde cinsiyet ve kültür, aktif yaşlanmanın anlaşılmasında kesişen etken (cross-cutting) olmaları bakımından çok önemlidir. Tüm bireyleri ve nüfusu çevreleyen kültür, aktif yaşlanmanın tüm belirleyicilerini etkileyerek yaşlanmayı şekillendirmektedir. Bu şekillenme kültürün çift yönlülügü ile ortaya çıkmaktadır. Her kültürel bağlamdan bireyler, kültürel değerleri yaşla içselleştirirler. $\mathrm{Bu}$ içselleştirilmiş kültürel değerler, yetişkin gelişimini yönlendiren hedefler haline gelmektedir (Fung, 2013: 369). Bu özellik, kültürün bireyi nasıl şekillendirdiğini göstermektedir. Kültürün diğer yönü ise bize, meseleyi tersinde ele alma imkanı sunmaktadır. Çünkü kültürel değerler ve gelenekler, toplumun yaşlı insanlara ve yaşlanma sürecine nasıl baktığını büyük ölçüde belirlemektedir. Öte yandan bu durumun (yaşlılara bakış açısının) tarihsel süreçte değişime uğradığını da belirtmekte fayda vardır. Nitekim sosyal yapılar değişirken yaşlanma ve yaşlılık da bu değişimden etkilenmekte, eski çağların görüşleri, toplum yapıları ve geleneklerinden örülü sosyal dünyanın içinde algılanan yaşlı ile modern çağın dünya görüşü, gelenekleri ve koşulları içinde algılanan yaşlı birbirinden farklı olmuştur (Tufan, 2016: 39). Bugün ise kişinin yaşlı oluşunu artık kronolojik yaşı değil, fiziksel, psikolojik, sosyal, ekonomik, eğitim durumu gibi pek çok faktör belirlemektedir. Bir diğer ifadeyle yaşlanma süreci toplumsal, sosyo-kültürel ve ekonomik olarak belirlenen çevresel faktörlerin de etkili olduğu çok boyutlu bir süreçtir. Aile, eğitim, kentleşme, kişi başına düşen gelir, işgücü ve gelir yapısında görülen değişimler bu çevresel faktörleri oluşturarak nüfusun, özelde de bireyin yaşlanmasına etki ederler. Toplumsal gelişme ve değişme sürecinde; geniş aileden çekirdek aileye geçiş, kadının işgücü piyasasına dahil olması, geleneksel kültürel değerlerin değişmesi gibi faktörler hem nüfus yapısının değişmesinde etkili olmakta hem de değişen/yaşlanan nüfusta yaşlılığa bakış ve yaşlı bireylerin bakım ihtiyaçların karşılanmasına ilişkin yaklaşımların değişmesine de neden olmaktadırlar (Hablemitoğlu ve Özmete, 2010: 50). Bununla birlikte kültür, genç nesillerle birlikte yaşamanın tercih edilen yaşam şekli olup olmadığı konusunda da önemli bir faktördür. Örneğin çoğu Asya ülkesinde birkaç neslin bir arada yaşadığ bilinmektedir. Buradan hareketle, politika oluşturulurken kültür ve gelenekler göz önünde bulundurulmalı ancak etik ve insan hakları gibi kültür üstü değerler göz ardı edilmemelidir (WHO, 2002: 20).

Bir diğer kesişen etken olan cinsiyetin, farklı politika seçeneklerinin uygulanmasında önemli bir rolü bulunmaktadır. Her ne kadar uzun ömürlülük ve cinsiyet arasındaki ilişki için tam kapsamlı araştırmalar mevcut değilse de, 
yaşlı kadınların yaşlı erkeklere oranının genelde 1,5:1; 90 yaş ve üzeri bireyler söz konusu olduğunda bu oranın 3:1 olduğu ifade edilebilmektedir (Hablemitoğlu, 2016: 119). Keza DSÖ’nün (2019: 3) Dünya Sağlık İstatistikleri Raporu kadınların erkeklerden daha uzun yaşadıklarını ortaya koymaktadır. Öte yandan kadınların eğitime, gelire, gıdaya, sağlık hizmetlerine, miraslara, sosyal güvenlik önlemlerine ve politik güce erişimde erkeklerle eşit olmadığı, erkeklere kıyasla aile içi şiddet ve ayrımcılığa maruz kalma olasılıklarının daha yüksek olduğu bilindiğinden, buradan hareketle oluşan dezavantajlar, uzun ömürlülük konusunda avantajlı gibi görünen kadınların yaşlılıkta erkeklere oranla daha yoksul olması sonucunu doğurmaktadır (WHO, 2002: 39). Benzer şekilde gerontolojik araştırmalar da yaşlılıkta kadının daha dezavantajlı olduğunu göstermektedir (Tufan, 2016: 92). Örneğin dul yaşlı erkeklerin daha genç kadınlarla evlenmelerine karşılık yalnız yaşayan dul kadınların sayısının hiç de azımsanmayacak boyutta olması, yoksulluk ve sosyal dışlanmaya maruz kalma oranlarının çok yüksek olmasını beraberinde getirdiği görülmektedir (Duben, 2018: 72). Bununla birlikte kadınlara ailede bakıcı olarak örtük bir şekilde tanımlanmış geleneksel rol de, kadınların ücretli bir işte çalışmalarına engel olabilmekte, bu da yaşl1lık döneminde artan yoksulluk ve kötü sağlık durumlarına katkıda bulunabilmektedir (WHO, 2008: 33). Buradan hareketle gerek kültürün gerekse cinsiyet faktörünün aktif yaşlanmada çok belirleyici etkenler olduğu bilinerek, bu iki faktörün kesişen etkisi olduğu ifade edilmektedir. Bunun haricinde aktif yaşlanma; sağlık ve sosyal hizmetler, davranışsal etkenler, bireysel etkenler, fiziki çevre, sosyal etkenler ve ekonomik etkenler bileşenlerinden oluşmaktadır.

Sağlık ve sosyal hizmetler bileşeni, aktif yaşlanmayı teşvik etmek için, sağlık sistemlerinin, sağlığı geliştirme, hastalık önleme ve kaliteli birinci basamak sağlık hizmetlerine ve uzun süreli bakım hizmetlerine eşit erişim konularına odaklanan bir yaşam seyri yaklaşımına sahip olması gerektiğini ifade eder. Sağlı ve sosyal hizmetlerin bütünleşik, eşgüdümlü ve uygun maliyetli olması ve bununla birlikte yaş ayrımcılığı yapmaması gerektiğini vurgular. Sağlıklı yaşam tarzlarının benimsenmesi ve kişinin kendi bakımına aktif olarak katılması yaşamın her aşamasında önemlidir. Yaşlandığında kişinin yeni yaşam tarzına uyum sağlamasının çok geç olduğu ise bir mittir, gerçeği yansıtmaz. Aksine, aktif yaşlanmanın davranışsal etkenlere göre; fiziksel aktivite, sağlıklı beslenme, sigara ve alkol kullanmama ve ilaç kullanımı ile hastalığın ve fonksiyonel yoksunluğun önlenmesi ile yaşam süresinin uzatılması ve yaşam kalitesinin artırılması mümkün olabilir. 
Aktif yaşlanmayı oluşturan bir diğer etken kişisel faktörlerdir. Yaşlanma, genetik olarak belirlenmiş bir biyolojik süreçtir. Bu yüzden de biyoloji ve genetik kişinin yaşl1lığının nasıl olacağını büyük ölçüde etkilemektedir. Bununla birlikte bireyin yaşlandığında sağlıklı ya da hasta olacağını belirleyen faktörler genetik, çevre, yaşam tarzı ve beslenmeden oluşan bir bileşiminin sonucu oluşmaktadır. Bunlara ek olarak, zeka ve bilişsel kapasite gibi psikolojik faktörler de aktif yaşlanma ve uzun ömürlülük için güçlü belirleyicilerdir.

Aktif yaşlanma etkenlerinden bir diğeri olan fiziki çevre, yaşanılan çevrenin yaş/yaşlı dostu olmasının, yaşlandıkça bağımlı ya da bağımsız kalabilmeyi belirlemesi açısından çok önemli olduğuna işaret eder. Yaşanılan çevre yaşlı dostu değilse, kişi daha izole yaşadığı için depresyona daha eğilimli olabilmekte, daha az hareket ettiği için de daha çok sağlık sorunları yaşayabilmektedir. Bununla birlikte fiziki ortamdaki tehlikeler, düşmeler, yangın ve trafik kazaları başta olmak üzere ağrılı yaralanmalara yol açabilir. Bunlara ek olarak, beraberinde sağlık ve sosyal hizmetlere ulaşım engeli de getirdiği için kırsal yaşlanmanın fiziki çevre bileşeni içinde önemli bir yeri vardır. Sonuç olarak aktif yaşlanma yaklaşımına göre; yaralanmaların büyük çoğunluğunun önlenebilir olduğu ancak geleneksel olarak "kaza" olarak görülmeleri nedeniyle halk sağlığında bu alanın tarihsel olarak ihmal edilmesine neden olduğu düşünülmektedir (WHO, 2002: 28).

Aktif yaşlanmaya ait bir diğer etken ise sosyal çevredir. Yaklaşım, sosyal desteğin, eğitimin ve yaşam boyu öğrenme firsatlarının yaşlandıkça sağlık, katılım ve güvenliği arttıran temel faktörler olduğunu savunmaktadır. Yetersiz sosyal desteğin sadece ölüm ve hastalık oranlarında ve psikolojik sıkıntıdaki artışla değil, genel sağlık ve esenlikte bir azalma ile de ilişkili olduğunu ifade etmektedir. Bununla birlikte istismar ve yaş ayrımcılığı da bu etkende ele alınmaktadır. Genellikle zayıf olan ya da yalnız yaşayan yaşlı insanlar, hırsızlık ve saldırı gibi suçlara karşı özellikle kendilerini savunmasız hissedebilmektedir. Yaşlıların (özellikle yaşlı kadınların) yaygın bir şekilde karşılaştıkları şiddet biçimi, aile üyeleri ya da bakıcılarının genellikle fail oldukları yaşlı istismarıdır. Yaklaşıma göre, yaşlı istismarı, fiziksel, cinsel, psikolojik ve mali istismarın yanı sıra ihmali de içermektedir. Bununla birlikte düşük eğitim düzeyi ile okuryazar olmamanın daha yüksek işsizlik oranlarının yanı sıra, yaşlandıkça insanlar arasındaki engellilik ve ölüm riskinin artmasına da etki eden bir diğer faktör olduğu vurgulanmaktadır. 
Aktif yaşlanma etkenlerinden sonuncusu ekonomik değişkenlere odaklanmaktadır. Gelir, iş ve sosyal korumadan oluşan ekonomik ortamın üç boyutu, aktif yaşlanma üzerinde önemli bir etkiye sahiptir. Bu bağlamda en dezavantajlı grubu özellikle kırsal alanda ve yalnız yaşayan yaşlı kadınların oluşturdukları bilinmektedir (WHO, 2002: 30). Bununla birlikte emekli maaş1 ya da sosyal güvenlik ödemesi olmayan, hiçbir mal varlığı, birikimi bulunmayan, düzenli ve yeterli geliri olmayan ailelerin parçası olan yaşlı kadın ve erkeklerin de bu bağlamda çok savunmasız oldukları görülmektedir. Sosyal koruma açısından bakıldığında da aile kurumunun yaşlıların ihtiyaç duydukları desteği almada başat konumda olduğu görülmektedir. Yaklaşıma göre; gelişen toplum yapısı ve birlikte yaşayan nesiller geleneği azalmaya başladıkça ülkelerin, geçimini sağlayamayan, yalnız ve savunmasız olan yaşlı insanlar için sosyal koruma sağlayan mekanizmalar geliştirme zorunluluğu ortaya çıkar. Öte yandan aktif yaşlanmaya göre iş bağlamında sadece formel işgücü piyasasında çalışmalara yoğunlaşmak, yaşlı insanların kayıt dışı sektörde (örneğin, küçük ölçekli, kendi hesabına çalışan faaliyetler ve ev işleri) ve evde ücretsiz çalışarak yaptıkları değerli katkıların göz ardı edilmesine neden olmaktadır (WHO, 2002: 30). Bununla birlikte gönüllü çalışmanın, toplumlara önemli bir katkı sağlarken, sosyal ilişkileri ve psikolojik iyi oluşu artırarak, yaşlı insanlara da yarar sağladığının altının çizilmesi gerektiğini iddia etmektedir.

Aktif yaşlanma yaklaşımı; yaşlanmanın sağlık ve sosyal hizmetler, davranışsal etkenler, kişisel etkenler, sosyal etkenler, ekonomik etkenler ve fiziki çevre ile ilişkili olduğunu ifade ederken politika önerisini sağlık, katılım ve güvenlikten oluşan üçlü sac ayağına oturtur (WHO, 2008: 34). Sağlık ayağı için yaklaşım; kronik rahatsızlıklar için çevresel ve davranışsal etkenlerin azaltılıp koruyucu faktörlerin artırılması durumunda insanların hem nicelik hem de nitelik yönünden yaşam kalitelerinin artacağını iddia etmektedir. Böylece daha az yaşlı, pahalı tıbbi tedavi ve bakım hizmetlerine ihtiyaç duyacaktır. Bakıma muhtaç olanların ise tüm sağlık ve sosyal hizmetlere erişimlerinin olması gerektiğini savunmaktadır.

Katılım ayağında aktif yaşlanma yaklaşımı, işgücü piyasası, istihdam, eğitim, sağlık ve sosyal politika ve programlarının, yaşlıların temel haklarına, kapasitelerine, ihtiyaçlarına ve tercihlerine göre sosyoekonomik, kültürel ve manevi aktivitelere katılımlarını destekleyecek şekilde yapılması gerektiği üzerinde durmaktadır. Bu sayede insanların, yaşlandıkça ücretli ve ücretsiz aktivitelerle topluma katk1 yapmaya devam edeceklerini iddia edilmektedir. 
Güvenlik için ise yaklaşım, politika ve programların, insanların yaşlandıkça sosyal, ekonomik ve fiziksel güvenlik ihtiyaçlarına hitap etmesi gerektiğini ifade etmektedir. Böyle olduğu takdirde, kendilerini destekleyemedikleri ve koruyamadıkları durumlarda kişiler korunmuş, onur ve bakımları garanti altına alınmış olur. Buradan hareketle DSÖ, ülkelerin aktif yaşlanmayı içeren politikalar üretmesi gerektiğinin altını çizmektedir. Sağlık, işgücü piyasası, istihdam ve eğitimi içeren sosyal politikaların, aktif yaşlanmayı desteklediğinde potansiyel olarak erken ölümlerin daha az olacağı, ileri yaşlarda karşılaşılan kronik hastalıklarda azalmanın gerçekleşeceği, daha çok kişinin yaşlandıkça yaşam kalitesinin artacağı, yaşlıların sosyal, kültürel, ekonomik ve politik yaşama daha çok katılım gerçekleştirecekleri ve son olarak da bakım ve sağlık hizmetleri masraflarının azalacağı iddia edilmektedir (WHO, 2002: 16). Öte yandan aktif yaşlanmanın yalnızca yaşlı bireylerin işgücü piyasalarına dahil edilmesi ile ilgili bir kavram olmadığı, gerek gönüllü çalışmalarla gerekse uyarlanmış konut ve altyapı sayesinde bağımsız olarak yaşama olanağıyla topluma aktif olarak katılmalarıyla ilgili bir yaklaşım olduğunun da altı çizilmelidir. Dolayısıyla da Avrupa Komisyonu, her ne kadar aktif yaşlanmaya ait çerçeve oluşturmada önemli bir yere sahipse de istihdam vurgusunu fazla yapması bakımından eleştirilmekte ve aktif yaşlanmayla ilgili olarak daha kapsamlı politika geliştirilmesine ihtiyaç duyulmaktadır (Foster ve Walker, 2015: 49).

\section{Aktif Yaşlanma Endeksi}

Toplumların yaşlanıyor olması yaşlanma kaynaklı sorunlara yönelik politika geliştirmeyi zorunlu kılmıştır. Avrupa 2020 Akıllı, Sürdürülebilir ve Kapsayıcı Büyüme Stratejisinde sosyal uyum ve daha yüksek üretkenlik için sağlıklı ve aktif yaşlanan nüfusu teşvik etmek için yaşanan/yaşanacak zorluk bağlamında aktif yaşlanmaya referans gösterilerek konunun önemi vurgulanmıştır (UNECE, 2013: 2). Bu kapsamda oluşturulacak sosyal politikaların geliştirilebilmesi için, yaşlılığa yönelik mevcut durum analizlerinin yapıldığı, yaşlılığın pek çok farklı boyutunun ortaya konduğu endeksler oluşturulmaktadır. ${ }^{1}$ Aktif yaşlanma endeksi ise bu endekslerin başında yer almaktadır. Avrupa Komisyonu, üye devletlerin sosyal yatırım politikalarını uygulamalarına yardımcı olacak bir dizi yol gösterici ilke olan Sosyal Yatırım Paketinin uygulanmasının izlenmesinde Aktif Yaşlanma

1 Hartford Yaşlanma Endeksi (Hartford Aging Index), Küresel Yaş İzleme Endeksi (Global Agewatch Index), Esenlik Endeksi (Ondex of Well-Being), Başarılı Yaşlanma Endeksi (Succesfull Aging Index), İnsan Gelişimi Endeksi (Human Development Index) başta olmak üzere pek çok erndeks farklı parametrelerle mevcut durum analizleri yapmaktadır. 
Endeksine büyük bir rol atfetmektedir (Manuel de Sao Jose vd., 2017: 50). Endeksin, kimi ülkelerin nasıl daha yüksek puanı olduğu, daha düşük puanlı ülkelerin nasıl motive edilebileceği, bazı ülkelerin aktif yaşlanmanın belirli alanlarında daha iyi neler yapabilecekleri, ülkelerin deneyimlerinin diğer ülkelere nasıl ders verebileceği gibi kimi "kritik politika sorularına" cevap vermede yardımcı olabileceği vurgulanmıştır (UNECE, 2015: 4).

AktifYaşlanma Endeksi (Active Ageing Index-AAI), Avrupa Komisyonu'nun İstihdam, Sosyal İşler ve Kaynaştırma Genel Müdürlüğü (DG EMPL) ve Birleşmiş Milletler Avrupa Ekonomik Komisyonu (UNECE) Nüfus Birimi tarafından ortaklaşa yönetilen bir projedir. Buradan hareketle proje kapsamında oluşturulan endeks "ulusal politika yapıcıların, nüfusun yaşlanmasının önündeki zorluklara başarılı tepkiler tasarlamalarını desteklemek için" oluşturulmuştur (UNECE, 2013: 3). Southampton Üniversitesi'nde Uluslararası Sosyal Politika profesörü Asghar Zaidi ve arkadaşları tarafından geliştirilen endeks, yaşlıların ulusal ve uluslar üstü düzeyde aktif ve sağlıklı yaşlanma için kullanılmayan potansiyelini ölçen bir araç olarak tanımlanmıştır. Geliştiricisi Viyana'daki Avrupa Sosyal Refah Politikası ve Araştırma Merkezi (European Centre for Social Workfare Policy and Research) olan 2012 AAI-I projesinin ilk aşamas1, Ocak 2012'den Şubat 2013'e kadar 27 Avrupa Birliği (AB) ülkesine uygulanmıştır.

AAI-II ise Ekim 2013'te başlayıp Nisan 2016'ya kadar devam etmiş ve kapsamına ilk projeden sonra $\mathrm{AB}$ ülkesi olan Hırvatistan ve dört $\mathrm{AB}$ üyesi olmayan Kanada, İzlanda, Norveç ve İsviçre dahil edilmiştir. Bununla birlikte 2008 ve 2012 verilerine göre hesaplanarak, 2010 ve 2014 AAI değerlerinin kapsamı genişletilmiştir. Mayıs 2016'da başlayan AAI-III ise Nisan 2019'da tamamlanmıştır (UNECE, 2019).

Endeks, yaşlı bireylerin bağımsız yaşama, ücretli istihdam ve sosyal etkinliklere katılma düzeylerini ve aktif olarak yaşlanma kapasitelerini ölçmektedir. Bu kapsamda yaşlı bireylerin, bireysel düzeyde aktif yaşlanma isteklerinin etkili kamu politikaları ve programları ile nasıl geliştirilebileceği önemlidir. Aktif yaşlanma endeksi, yaşlanan bireyin aktivitelerine ve bağımsızlığına karşılaştırmalı bir bakış ortaya koyarak, ülkelere bu bağlamda yardımcı olmaktadır. Buradan hareketle endeksin hedefi, politika yapıcılara öncelikli alanları göstermek olarak belirlenmiştir (UNECE, 2015: 10). Yapılan ülke kıyaslamalarıyla hangi ülkelerin hangi alanlarda daha iyi oldukları 
görülebilmekte ve böylece ülkelerin politika belirlemelerine yardımcı olunabilmektedir. Bir diğer ifadeyle Aktif yaşlanma endeksi, politika yapıcılar için, nüfusun yaşlanmasının zorlukları ve toplum üzerindeki etkileri ile ilgili kanıta dayalı stratejiler geliştirmelerini sağlayacak yeni bir araç sağlamaktadır (UNECE, 2014).

Aktif yaşlanma endeksi, (niteliksel) bir bileşik endekstir, diğer bir ifadeyle birkaç gösterge tarafından alındığı ve bu göstergelerin tek bir genel endekste toplanabileceği anlamına gelmektedir (Ravallion, 2010). Temelde dört ana parametre ve bu parametrelere ait alt bileşenlerden oluşmaktadır. İstihdam, Katılım, Bağımsız Sağlıklı ve Güvenli Yaşam ile Aktif Yaşlanma için Kapasite ve Elverişli Ortam bu dört ana parametreyi oluşturur. İlk üç parametre, yaşlı kişilerin dahil olduğu çeşitli aktivitelerin yanı sıra bağımsız, özerk ve güvenli yaşam deneyimlerini yansıtan "gerçek deneyimlere" atıfta bulunmaktadır. Dördüncü parametre, aktif yaşlanmayı kolaylaştıran veya engelleyen çevresel ve yaşlı kişilerin bireysel özelliklerine göre aktif yaşlanma için kapasite ve uygun ortamları vurgular (UNECE, 2014). Alt bileşenler de hesaba katıldığında endeksin hesaplanmasında toplam 22 göstergeye bakıldığı görülür. Her bir göstergenin endeks hesaplamasında farklı bir ağırlığg vardır ve her bir gösterge toplanarak toplamda 0'dan 100'e kadar bir değere ulaşılır (Tablo 2). 100 puanın ulaşılması imkansız bir hedef olduğu bilinmekle birlikte, sonuçlar ne kadar yüksekse yaşlı bireylerin ekonomiye ve topluma katkıda bulunma potansiyellerinin o kadar yüksek olduğu, bununla birlikte yaşadıkları çevrenin aktif yaşlanmalarını mümkün kıldığı varsayılmaktadır (UNECE, 2016., Manuel de Sao Jose vd., 2017: 52).

Tablo 2

Aktif Yaşlanma Bileşenleri ve A ğırlıkları

\begin{tabular}{|c|c|c|c|}
\hline Bileşenler & $\begin{array}{c}\text { Genel } \\
\text { endeks } \\
\text { içindeki } \\
\text { alan } \\
\text { ağırlığı }\end{array}$ & Göstergeler & $\begin{array}{c}\text { Alan } \\
\text { içindeki } \\
\text { gösterge } \\
\text { ağırlığı }\end{array}$ \\
\hline \multirow[t]{4}{*}{ 1.İstihdam } & $\% 35$ & 1.1. İstihdam Oran1, 55-59 & $\% 25$ \\
\hline & & 1.2. İstihdam Oran1, 60-64 & $\% 25$ \\
\hline & & 1.3. İstihdam Oran1, 65-69 & $\% 25$ \\
\hline & & 1.4. İstihdam Oran1, 70-74 & $\% 25$ \\
\hline
\end{tabular}




\begin{tabular}{|c|c|c|c|}
\hline \multirow[t]{4}{*}{ 2.Kat1lım } & \multirow[t]{4}{*}{$\% 35$} & 2.1.Gönüllü Çalışma & $\% 25$ \\
\hline & & 2.2.Çocuk/torun Bakımı & $\% 25$ \\
\hline & & 2.3.Yaşlı Bakımı & $\% 30$ \\
\hline & & 2.4.Politikaya Katılım & $\% 20$ \\
\hline \multicolumn{4}{|l|}{$\% 100$} \\
\hline \multirow{8}{*}{$\begin{array}{l}\text { 3.Bağımsı, } \\
\text { Sağlıklı } \\
\text { ve } \\
\text { Güvenli Yaşam }\end{array}$} & \multirow[t]{8}{*}{$\% 10$} & 3.1.Fiziksel Egzersiz & $\% 10$ \\
\hline & & 3.2.Sağlık Hizmetlerine Erişim/ Memnuniyet & $\% 20$ \\
\hline & & 3.3.Bağımsız Yaşam Düzenlemeleri & $\% 20$ \\
\hline & & 3.4.Göreli Medyan Gelir & $\% 10$ \\
\hline & & 3.5. Yoksulluk Riskinin Olmamas1 & $\% 10$ \\
\hline & & 3.6.Şiddetli (?) Maddi Yoksunluğun Olmaması & $\% 10$ \\
\hline & & 3.7.Fiziki Güvenlik & $\% 10$ \\
\hline & & 3.8. Yaşam Boyu Öğrenme & $\% 10$ \\
\hline \multicolumn{4}{|l|}{$\% 100$} \\
\hline \multirow{6}{*}{$\begin{array}{l}\text { 4.Aktif Yaşlanma } \\
\text { için Kapasite ve } \\
\text { Elverişli Ortam }\end{array}$} & \multirow[t]{6}{*}{$\% 20$} & 4.1. Yaşam Beklentisi & $\% 33$ \\
\hline & & 4.2. Sağlıklı Yaşam Beklentisi & $\% 23$ \\
\hline & & 4.3. Mental İyilik Hali/esenlik & $\% 17$ \\
\hline & & $\begin{array}{l}\text { 4.4. Bilişim ve İletişim Teknolojilerinin } \\
\text { Kullanımı }\end{array}$ & $\% 7$ \\
\hline & & 4.5. Sosyal Bağlanabilirlik & $\% 13$ \\
\hline & & 4.6. Eğitim Düzeyi & $\% 7$ \\
\hline
\end{tabular}

Kaynak: (UNECE, 2015: 17)

2012 yılının AB tarafindan Avrupa Aktif Yaşlanma ve Nesillerarası Dayanışma Yılı olarak belirlenmiş olması da yaşlanmaya ilişkin farkındalığın artırılmasına yönelik bir çaba olarak görülebilir. Bu kapsamda mevcut durum analizini yapmak üzere ilki 2012 yılında sonuçlanan AB üye ülkelerinin aktif yaşlanma endeksleri hesaplanmıştır. Araştırma sonuçları, AB İşgücü Anketi (EU Labour Force Survey), AB Yaşam Kalitesi Anketi (European Quality of Life Survey), AB Gelir ve Yaşam Koşulları Anketi (EU Survey of Income and Living Conditions), Avrupa Sosyal Taraması Anketi (European Social Survey), Avrupa Sağlık ve Yaşam Beklentisi Bilgi Sistemi (JA EHLEIS) ve Avrupa Bilişim ve İletişim Teknolojileri Anketi (European ICT Survey) araştırmalarından elde edilen bulgulardan derlenmiştir. 2014 yılında çalışma tekrarlanmış ve sonuçların 2012 yılında yapılan çalışmayla mukayese edilme firsatı doğmuş, yapılan kıyaslama sonucunda ülkelere nüfusun yaşlanmasına bağlı olarak oluşacak sorunları ve firsatları belirlemek için bir çerçeve sunulmuştur (UNECE, 2015: 1). 
Tablo 3

Aktif Yaşlanma Endeksine göre Ülke Stralamaları (2010, 2012, 2014, 2016)

\begin{tabular}{|c|c|c|c|c|c|c|c|c|}
\hline Ülkeler & $\begin{array}{l}\text { AAI } \\
2010 \\
\end{array}$ & Siralama & $\begin{array}{r}\text { AAI } \\
2012 \\
\end{array}$ & Siralama & $\begin{array}{l}\text { AAI } \\
2014 \\
\end{array}$ & Siralama & $\begin{array}{l}\text { AAI } \\
2016 \\
\end{array}$ & Siralama \\
\hline İsveç & 42,6 & 1 & 44,2 & 1 & 44,9 & 1 & 46,9 & 1 \\
\hline Danimarka & 38,8 & 2 & 40 & 2 & 40,3 & 2 & 42,7 & 2 \\
\hline Hollanda & 38,6 & 3 & 38,9 & 4 & 40 & 3 & 42,4 & 3 \\
\hline İngiltere & 38 & 4 & 39,7 & 3 & 39,7 & 4 & 41,3 & 4 \\
\hline Finlandiya & 36,9 & 5 & 38,3 & 6 & 39 & 5 & 40,6 & 5 \\
\hline Almanya & 34,3 & 7 & 34,3 & 9 & 35,4 & 9 & 39,5 & 6 \\
\hline İrlanda & 35,8 & 6 & 38,5 & 5 & 38,6 & 6 & 39 & 7 \\
\hline Fransa & 33 & 9 & 34,3 & 10 & 35,8 & 7 & 38,4 & 8 \\
\hline Estonya & 33,4 & 8 & 32,9 & 16 & 34,6 & 10 & 38,1 & 9 \\
\hline Belçika & 32,4 & 10 & 33,2 & 15 & 33,7 & 15 & 37,7 & 10 \\
\hline Çek Cum. & 31 & 16 & 33,8 & 12 & 34,4 & 11 & 36,5 & 11 \\
\hline Avusturya & 31,3 & 15 & 33,6 & 14 & 34,1 & 13 & 35,9 & 12 \\
\hline Kibris & 32,4 & 11 & 35,7 & 7 & 34,2 & 12 & 35,8 & 13 \\
\hline Letonya & 32,2 & 13 & 29,6 & 22 & 31,5 & 21 & 35,7 & 14 \\
\hline $\mathrm{AB}$ ortalamas1 & 32 & & 33,4 & & 33,9 & & 35,8 & \\
\hline Malta & 28 & 24 & 30,6 & 20 & 31,5 & 20 & 35,5 & 15 \\
\hline Lüksemburg & 31,8 & 14 & 35,2 & 8 & 35,7 & 8 & 35,3 & 16 \\
\hline İspanya & 30,4 & 17 & 32,5 & 17 & 32,6 & 17 & 34,1 & 17 \\
\hline İtalya & 30,1 & 19 & 33,8 & 13 & 34 & 14 & 34 & 18 \\
\hline Portekiz & 32,3 & 12 & 34,1 & 11 & 33,5 & 16 & 33,9 & 19 \\
\hline Litvanya & 30,1 & 18 & 30,7 & 19 & 31,5 & 19 & 33,6 & 20 \\
\hline Slovakya & 26,8 & 27 & 27,7 & 26 & 28,5 & 25 & 32,8 & 21 \\
\hline Bulgaristan & 26,9 & 26 & 29,4 & 24 & 29,9 & 22 & 32 & 22 \\
\hline Polonya & 27 & 25 & 27,1 & 28 & 28,1 & 27 & 31,5 & 23 \\
\hline Slovenya & 30 & 20 & 20,5 & 21 & 29,8 & 23 & 31 & 24 \\
\hline Macaristan & 26,3 & 28 & 27,5 & 27 & 28,3 & 26 & 30,7 & 25 \\
\hline Romanya & 29,4 & 21 & 29,4 & 23 & 29,6 & 24 & 30,4 & 26 \\
\hline Hirvatistan & 28,3 & 23 & 30,8 & 18 & 31,6 & 18 & 29,7 & 27 \\
\hline Yunanistan & 28,7 & 22 & 29 & 25 & 27,6 & 28 & 28,1 & 28 \\
\hline Türkiye* & & & - & - & 27,6 & - & & \\
\hline
\end{tabular}

*2016 yılında yayımlanan AAI'nin Türkiye pilot çalışması sonuçları yazar tarafından listeye dahil edilmiştir. Kaynak: (UNECE, 2015: 11; UNECE, 2019:19).

2010, 2012, 2014 ve 2016 yıllarında yapılan araştırmalar birbirleriyle kıyaslandığında endeks puanı en yüksek ülkelerle, listede sonlarda yer alan ülkelerin çok fazla değişmediği gözlenmekle birlikte orta sıralarda bazı farklılıklar göze çarpmaktadır (Tablo 3). Bu bağlamda İsveç, Danimarka, Finlandiya, Hollanda ve İngiltere'nin endeks sıralamasında ilk beşte, Slovenya, Macaristan, Yunanistan, Romanya ve Hırvatistan'ın da araştırmalarda sonlarda olduğu görülmektedir. Öte yandan son yapılan araştırma sonucunda hemen hemen her ülke için söylenebilecek olan küçük de olsa endeks puanlarında artış 
olduğudur (Hırvatistan hariç). Endeksin cinsiyetler arası farklılıkları da ortaya koyabildiği düşünüldüğünde, toplam endeks puanları açısından erkeklerin hemen hemen bütün ülkelerde (Finlandiya, Fransa ve Estonya hariç), kadınlardan daha yüksek puana sahip oldukları söylenebilir (UNECE, 2019: 26)

AAI her ne kadar AB ülkelerini kapsıyor olsa da 2014 yılında başlayan bir pilot çalışmada Gürcistan, Sırbistan ve Türkiye'ye ait veriler toplanarak belirli bir bölgenin ya da $\mathrm{AB}$ üyesi olmayan ülkelerin endeks puanının hesaplanıp hesaplanamayacağı ölçülmüş̧ür. Türkiye verilerinin tamamlanması 2015 yılını bulurken, kimi veriler (Fiziki güvenlik, Sağlıklı Yaşam Beklentisi, Sosyal Bağlanabilirlik) önceki yıllarda yapılan çalışmalardan derlenmiş̧tir (UNECE, 2016).

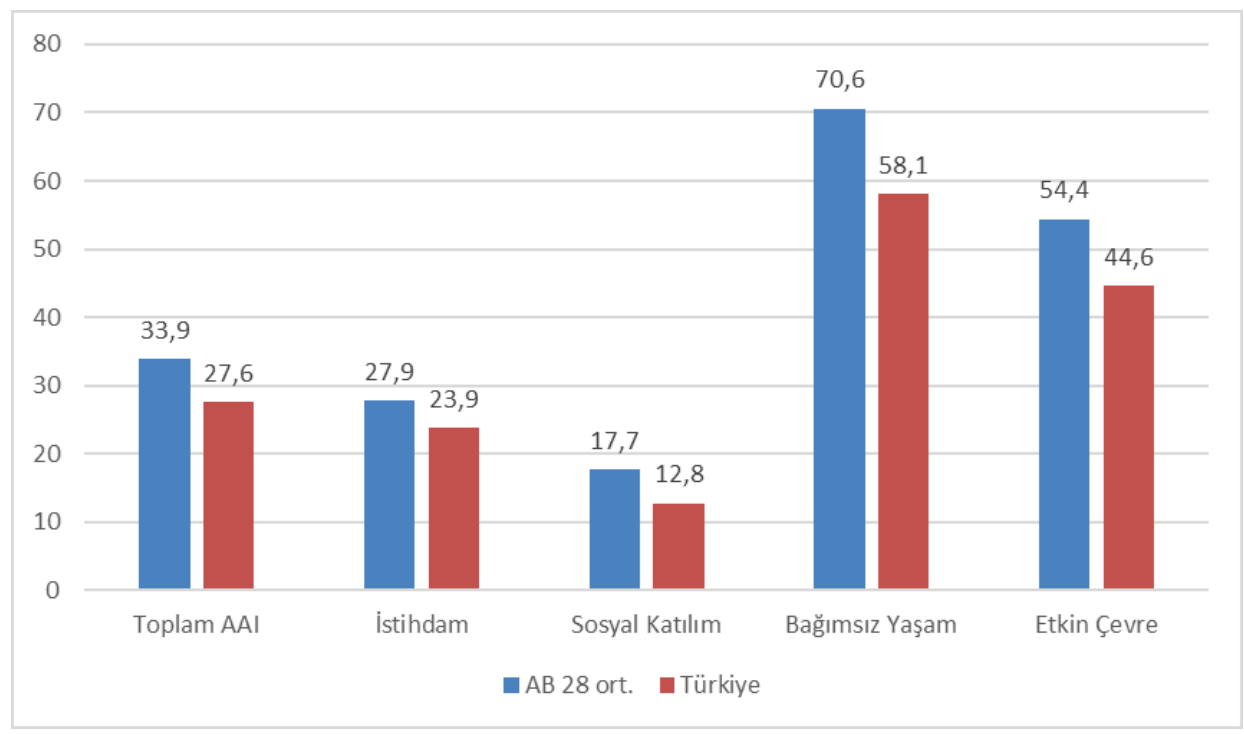

Grafik 3. 2014 AAI AB ortalaması ve Türkiye Karşılaştırması Kaynak: (UNECE, 2016: 2)

Yapılan pilot çalışmayla her ne kadar tüm alanlarda $\mathrm{AB}$ ortalamasının gerisinde kalsa da Türkiye için yaşlı bireylerin potansiyellerinin kullanılabileceği bir gelişim alanının olduğu ortaya çıkmıştır. Çalışma dikkatli bir şekilde incelendiğinde, Türkiye'nin en önemli potansiyelinin kadın istihdamında ortaya çıkabileceği görülmektedir. Nitekim endeks puanı açısından belirgin farka neden olan durum, Türkiye'deki kadın istihdam oranının, $\mathrm{AB}$ ortalamasının 
çok gerisinde olmasıdır (UNECE, 2016: 9). Dolayısıyla politika yapıcılar için bu tespit hareket noktası olabilir ve bu kapsamda üretilecek uygulamalarla Türkiye yukarıda ifade edilen potansiyeli geliştirebilir.

AAI, yaşlı bireyleri politika açısından yalnızca emeklilik geliri olarak değil, aynı zamanda sağlığın teşviki, uzun çalışma kariyerleri ve topluma katılımın sürdürülmesi gibi daha geniş yaşam alanlarında da ele almaktadır. Buradan hareketle Aktif yaşlanma endeksinin, daha aktif ve daha sağlıklı yaşlanma potansiyeli hedefine ulaşmak için var olan potansiyeli ölçmeyi hedeflediği ifade edilmelidir. Mevcut durumun sayılarla ifade edilmesi ya da bir başka ifadeyle somut olarak ortaya konması ve uluslararası karşılaştırmalara imkân verdiği için politika yapıcılar açısından iyileştirmeler için hedefler belirlemede yardımcı olacaktır. Bununla birlikte endeksin çok boyutlu analizler açısından katma değer sağladığı, aynı zamanda ülkeye özgü analizler için aktif ve sağlıklı yaşlanmaya dair bireysel perspektifler hakkında da önemli veriler ortaya koyduğu ifade edilmelidir (Zaidi, 2015).

Aşağıda aktif yaşlanma endeksini oluşturan parametreler ayrıntılı olarak incelenecektir.

\section{İstihdam}

Aktif yaşlanma endeksini oluşturan ana bileşenlerin başında istihdam gelmektedir. Yetişkin yaşamı boyunca belirleyici olan istihdam, bireyin yaşlılığa yönelik mali hazırlığını büyük ölçüde etkilemektedir (WHO, 2002: 20). Bununla birlikte Avrupa genelinde yaşam beklentisi arttıkça, emeklilik yaşları artmakta, ancak yaşlıların bir çoğu mevcut işlerinde kalamayacakları ya da iyi bir emekli maaşı için emekli olana kadar başka bir iş bulmayacaklarından korkmaktadır. Buradan hareketle aktif yaşlanma yaklaşımı yaşlı çalışanlar için işgücü piyasasında daha çok firsat sunulması gerektiğini iddia etmektedir (UNECE, 2013: 6). Öte yandan yaşlı bireylerin istihdam oranlarını artırmak bütünsel bir aktif yaşlanma ölçütü değildir; işyerinde yaş ayrımcılığına karşı mücadele, daha esnek istihdam biçimleri ve/veya eğitim firsatlarını teşvik etme gibi önlemlerin istihdam teşviklerine eşlik etmesi gerekmektedir (Foster ve Walker, 2015).

Hem yaşlı yoksulluğunun azaltılması hem de aktif yaşlanma açısından, erken emeklilik istenen bir durum olmadığından endeks hesaplamasında bireyin ücretli bir işte çalışıyor olmasının endeks puanına etkisinin (\%35) büyük olduğu 
görülmektedir (Tablo 2). Buradan hareketle endeksin ilk ana parametresi olan istihdam her ne kadar kendi içinde dört alt bileşene (55-59, 60-64, 65-69 ve 70-74 yaş istihdam oranları) bölünse de bu alan için ülkelerin yalnızca bu yaş aralıklarındaki istihdam oranları sorulmaktadır. Dolayısıyla istihdam bileşeninden tam puan almak için yalnızca ücretli bir işte çalışıyor olmak yeterlidir.

İstihdam oranları, ülkeler arasında kıyaslama yapmak açısından önemlidir. Nitekim Kuzey ülkeleri ile İngiltere ve Almanya gibi bazı Batı Avrupa ülkelerinin, emeklilik yaşına ulaşan işçilerin istihdam seviyelerini sürdürmede daha başarılı oldukları görülmektedir. Bu başarının en önemli nedeni hiç kuşkusuz kadın istihdam oranlarının erkek istihdam oranlarına yakın oluşundan kaynaklanmaktadır (UNECE, 2015: 8). Bu durum ne yazık ki Türkiye için geçerli değildir. Özellikle cinsiyetler arasındaki fark açısından Türkiye olumsuz örneklerden biri konumundadır. \% 34,4 yaşlı erkek istihdam oranına karşı \% 13,4 yaşlı kadın istihdam oranı, cinsiyetler arasındaki makasın çok açık olduğunu göstermektedir. Toplam değer üzerinden değerlendirilme yapıldığında da Türkiye'nin \% 23,9 istihdam oranıla AB ülkeleri arasında 18. sırada yer aldığı görülmektedir (UNECE, 2016).

Bir ülkenin istihdam alanı endeksi, en iyi performans gösteren ülkeye göre daha yaşlı çalışanların istihdam edilmesine ek olarak ne gibi potansiyellerin gerçekleştirilebileceğinin niceliksel değerlendirmesini sağlaması bakımından önemlidir. Öte yandan bu ülkelerdeki yüksek istihdam puanlarının bir kısmı, istihdamda daha uzun süre kalmak için insanların emekli olmalarını zorlaştıran sorunlarını yansıtıyor olabilmektedir. Bir diğer saptama da özellikle endüstrileşmiş ülkelerde erken emekliliğe yönelik mevcut eğilimin büyük ölçüde işgücünün işgücü piyasasından erken çekilmesini teşvik eden kamu politikalarının sonucu olduğu şeklindedir (WHO, 2002: 16). Bir diğer önemli nokta ise işgücü piyasalarında sıklıkla yaşanan yaş ayrımcılığı konusudur. İş ilanlarındaki yaş sınırlamalarından, işverenlerin genellikle eğitim programlarına girişi 50 yaş altı çalışanlarla sınırlamalarına, yaşlıların eğitilmelerinin zor olduğu, fazla ihtiyatlı davrandıkları, yeni teknolojilere uyum sağlayamadıkları ve esnek olmadıkları önyargılarına kadar pek çok konuda ayrımcılık yapıldığı görülmektedir (Alcock, May ve Rowlingson, 2011: 515). Buradan hareketle hem Avrupa ülkelerinde hem de Türkiye'de bireylerin büyük bir kısmının 65 yaşına kadar çalışmayı tercih etmedikleri bilindiğinden, bireylerin uzun süre çalışma yaşamında kalmalarını sağlayacak donanıma sahip olmaları için eğitim 
programlarına ve emekliliğe kademeli geçişe ihtiyaç duyulmaktadır (Kalkınma Bakanlığ1, 2014: 29). Ancak bu noktada az gelişmiş ülkelerde yaşlı nüfusun işgücü piyasasının içinde olmasının, hayatlarını idame ettirme zorunluluğundan kaynaklandığ1 (WHO, 2002: 31), dolayısıyla da ücretli çalışmanın bu yaşı nüfus için bir tercih değil zorunluluk olduğu da göz ardı edilmemelidir. Benzer şekilde AB ülkesi olan Estonya'daki yüksek istihdamın düşük emeklilik gelirlerini yansıttığı iddia edilebilir. Nitekim AB ortalamasıyla karşılaştırıldığında Estonya, \% 86'ya karşıl1k \% 72 gibi bir oranla, göreli medyan gelir açısından en düşük $\mathrm{AB}$ ülkelerinden biridir ve bu durum Estonya'da yaşlı bireylerin işgücü piyasası içinde kalmalarını görece bir zorunluluğa dönüştürebilmektedir (UNECE, 2015: 23). Ya da benzer bakış açısından hareketle yüksek emeklilik gelirlerinin Lüksemburg'da düşük istihdam oranına etkide bulunduğu söylenebilir (UNECE, 2014: 7).

\section{Sosyal Katılım}

Aktif yaşlanma endeksini oluşturan ana parametrelerden ikincisi sosyal katılımdır. Sosyal katılım parametresi kendi içinde dört bileşenden oluşur. $\mathrm{Bu}$ bileşenler, gönüllü çalışmayı, çocuk/torun ve yaşlı bakımı ile politikaya katılımı içermektedir. Her bir bileşenin sosyal katılım parametresine etkisi farklı ağırlıklardadır. Bununla birlikte toplam endeks hesaplamasında sosyal katılım parametresinin etkisi ile ilk parametre olan istihdam etkisinin aynı ve en yüksek değerde olduğu ifade edilmelidir. Burada anlatılmak istenen, yaşlı bireyin ücretli bir çalışma gerçekleştirmesiyle ücretsiz olarak gönüllü aktivitelerde bulunması, çocuğuna, torununa, yaşlıya bakması ya da politikayla ilgilenmesi gibi topluma katılım göstermesi aynı oranla değerli ve etkili olduğudur.

Endeks, yaşlı bireyin çocuk, torun veya yaşlı bakıcılı̆̆ 1 yapmasının topluma katılımında çok önemli bir faktör olduğunu iddia eder. Bu durumun bir çeşit gönüllülük olduğunu ve yaşlı bireylerin bu katkıları sayesinde istihdama katkıda bulunduklarını varsayar. Nitekim İtalya örneğinde ve diğer AB ülkelerinde olduğu gibi, özellikle artan emeklilik yaşı nedeniyle kadınların daha uzun sürelerde işgücü piyasasında yer alıyor/alacak olmaları nedeniyle çocuk, torun ve yaşlı bakımı konularında iş-yaşam dengesi açısından baskı yaşayacakları düşünülmektedir (Zaidi vd., 2013: 6; UNECE, 2015: 23). Örneğin, Fransa ve İtalya'nın sosyal katılım parametresine göre üst sıralarda yer alması, diğer AB ülkelerine kıyasla görece daha erken işgücü piyasasından ayrılmalarıyla 
ilişkilendirilebilmektedir. Cinsiyetler açısından değerlendirme yapıldığında genel olarak kadınların gönüllü aktivitelere ve politikaya katılımlarının erkeklere göre daha düşük, çocuk, torun ve yaşlı bakımlarında erkeklerden daha yüksek değerlere sahip oldukları görülür (UNECE, 2014: 7).

2016 yılında yayımlanan pilot çalışma sonucuna göre Türkiye, 12,8 puanla AB ülkeleri sıralamasında 25. sırada yer almaktadır. Türkiye'nin bu sıralamada yer alması çocuk/torun ${ }^{2}$ ve yaşlı bakımındaki görece yüksek orandan kaynaklanmaktadır. Örneğin Türkiye'de \% 14,3 gibi bir oranla yaşlılar, yaşlı bakımını gerçekleştirmektedir ki bu oran $\mathrm{AB}$ ortalamasının üstündedir. Buna karşılık gerek politik katılım gerekse gönüllü çalışma konusunda Türkiye'nin değerleri çok düşüktür. Gönüllü çalışmalara dahil olan yaşlılar neredeyse yokken (\% 0,5), politik katılım yalnızca \% 4 civarındadır (UNECE; 2016). Buna karşılık cinsiyet özelinde değerlendirme yapıldığında sosyal katılım parametresine göre Türkiye'de kadınların erkeklere göre daha yüksek puan aldıkları görülmektedir. Kuşkusuz bu durum kadının toplumsal cinsiyet rollerine işaret eden çocuk, torun ve yaşlı bakımını içeren parametreden kaynaklanmaktadır. Nitekim Türkiye'de kadınların vermiş oldukları bakım hizmeti AB ortalamasının çok üstünde seyretmektedir (UNECE, 2016).

\section{Bağımsız, Sağlıklı ve Güvenli Yaşam}

Aktif yaşlanma endeksinin üçüncü ana parametresi bağımsı, sağlıklı ve güvenli yaşamın farklı yönlerini kapsamaktadır. Parametre kendi içinde sekiz bileşenden ve farklı ağırlıklardan oluşur. Bağımsız, Sağlıklı ve Güvenli Yaşam parametresi aktif yaşlanma endeksi içinde endekse \%10 gibi küçük bir oranla etki etse de içinde, fiziksel egzersiz, sağlık hizmetlerine erişim, fiziki güvenlik ya da yoksulluk riskinin olmaması gibi önemli bileşenleri barındırmaktadır. Aktif yaşlanma yaklaşımı, yaşlandıkça sağlıkla ilgili sorunların arttı̆̆ını kabul etmekle birlikte, yaşlı bireyin çevresinde yapılacak küçük değişikliklerle çeşitli sağlık sorunlarının ve engellerin ortadan kalkabileceğini bu durumun bu tarz engellere maruz bireylerin hayatında büyük farklar yaratacağını iddia eder (UNECE, 2013: 7). Bu bağlamda aktif yaşlanma, yaşlandıkça güçlenmek ve böylece mümkün olduğu kadar uzun süre yaşlıların kendi hayatlarından sorumlu olmaları anlamına gelir (Zaidi vd., 2013: 6).

2 Anne olan kadınların istihdamda kalmasını sağlamak amacıyla Büyükanne Projesi adıyla 2017 Ocak ayında başlayıp bir yıl süre süren proje kapsamında torununa bakan büyükanneye (6 bin 500 kişi) 12 ay boyunca karşılıksız olarak 425 TL destek verilmiştir. 
Fiziksel egzersiz bileşeni, kişinin düzenli fiziksel aktivitelerde bulunmasını aktif yaşlanmanın önemli bir bileşeni sayar. Örneğin, düzenli fiziksel aktiviteyi teşvik eden önlemler için 1 \$'llk yatırımın tıbbi maliyetlerde 3.2 \$'llk bir maliyet tasarrufuna yol açtığı tahmin edilmektedir (U.S. Centers for Disease Control, 1999). Bununla birlikte sağlık hizmetlerine ulaşmada sıkıntı yaşanıp yaşanmaması bir diğer önemli faktördür. Bağımsız yaşam düzenlemeleri adını taşıyan bileşen bireyin, yalnız ya da eşiyle yaşayabilme kapasitesini ölçer. Göreli medyan gelir, yoksulluk riskinin olmaması ve maddi yoksunluğun bulunmaması bileşenleri, yaşlı bireyin ekonomik durumunun ölçüldüğü bileşenlerdir. Fiziki güvenlik bileşeni ise yaşlı bireyin yaşadığı çevrede özellikle de hava karardığında kendini güvende hissedip hissetmediğine odaklanır. Son olarak yaşam boyu öğrenme bileşeni yaşlı bireyin kendini geliştirmek adına son zamanlarda katılmış olduğu eğitim programlarının olup olmadığını sorgular. Yukarıda ifade edilen sekiz bileşen farklı ağırlıklara sahip olup toplamda bağımsız, sağlıklı ve güvenli yaşam parametresini oluşturmaktadır. Örneğin Danimarka, Finlandiya ve Hollanda, bu parametre açısından ilk sırada yer alan ülkelerdir. Yıllara göre bakıldığında Bulgaristan haricindeki ülkelerde belirgin farklılaşmanın yaşanmadı̆̆ı görülmektedir. Bulgaristan'ın yarattığ farklılık ise son yıllarda sağlık hizmetlerine ulaşım ve yoksulluk konusunda göstermiş olduğu gelişmelerden kaynaklanmaktadır (UNECE, 2015: 39).

Üçüncü ana parametre olan Bağımsız, Sağlıklı ve Güvenli Yaşam parametresi cinsiyet bağlamında değerlendirildiğinde, özellikle ekonominin ve fiziksel güvenliğin sorgulandığı bileşenlerde bütün $\mathrm{AB}$ ülkelerinde kadınların erkeklerden daha kötü durumda olduğu görülmektedir. Bu noktada Malta'nın istisnai bir durumu vardır. Malta'da kadınlar fiziksel egzersiz konusunda erkeklerden daha yüksek puana sahip olduğundan alan endeks puanları erkeklerden daha yüksektir (UNEC, 2014: 10). Benzer şekilde Türkiye pilot çalışmasında da kadınların erkeklerden daha çok fiziksel aktivite yaptıkları sonucuna ulaşılmıştır. Bütün olarak değerlendirildiğinde ise Bağımsız, Sağlıklı ve Güvenli Yaşam parametresi açısından Türkiye yapılan pilot çalışmayla 58.1 puanla tüm AB ülkeleri arasında en alt sırada yer almaktadır. Yalnızca ortanca gelir ve fiziki güvenlik bileşenlerinde Türkiye değerleri AB ortalamasının üstünde seyretmektedir. Türkiye'de yaşlıların \% 72'si yaşadıkları çevrede ve hava karardığında yalnız yürürken kendilerini güvende hissettiklerini belirtmişlerdir. Yine Türkiye' de yaşlıların büyük bir çoğunluğu (\% 79), sağlık ihtiyaçlarının karşılandığını ifade etmiştir. Türkiye'de 75 yaş üstü nüfusun 
yalnız ya da eşiyle birlikte yaşama oranı ise \% 60'tır. Buna karşılık yalnızca \% 2 gibi çok küçük oranla yaşlılar, yaşam boyu öğrenme adına etkinliklere katıldıklarını beyan etmişlerdir (UNECE, 2016: 18).

\section{Aktif Yaşlanma için Kapasite ve Elverişli Ortam}

Aktif yaşlanma endeksini oluşturan son parametre, diğerlerinden farklı olarak aktif yaşlanmayı kolaylaştıracak faktörler için bir ön koşul olarak değerlendirilebilir. Bir diğer ifadeyle yukarıdaki üç parametreye ek olarak, "aktif yaşlanma için ortam ve olanak sağlayan ortam" ilk üç parametrenin temeli olarak kabul edilir (Zaidi vd., 2013: 6). Aktif yaşlanma potansiyeline işaret eder. Kendi içinde altı bileşenden ve farklı ağırlıklardan oluşan Aktif Yaşlanma için Kapasite ve Elverişli Ortam parametresi için aktif yaşlanmada öncelik uzun ve sağlıklı yaşamı hedeflemektir. Aktif yaşlanma sermayesi açısından diğer önemli göstergeler, yaşlı bireyin internet kullanımı, sosyal ilişkileri ve eğitiminden oluşur.

$\mathrm{Bu}$ parametre açısından da öngörülebilecek olan toplam aktif yaşlanma puanları yüksek olan İsviçre, Danimarka, Lüksemburg ve Hollanda gibi ülkelerin burada da ilk sıralara yerleşmiş olmasıdır. Buna karşılık Kıbrıs ve Portekiz'in toplamda görece daha aktif olmasına rağmen düşük bir potansiyeli olduğunu görmek mümkündür. Portekiz ve İspanya'da ise yaşlı bireylerin sosyal bağlanabilirlikleri diğer ülkelerin çok üzerindedir. Buna karşılık Almanya ile Orta ve Doğu Avrupa ülkelerinde yaşl1lar, sosyal olarak daha izoledir. Eğitim düzeyi ile ilgili olarak ise Portekiz, Malta, İspanya, İtalya ve Yunanistan'ın, AB ortalamasının oldukça gerisinde olduğu belirtilmelidir. Cinsiyetler arasındaki farka bakıldığında ise kadın ve erkekler arasında birinci parametredeki kadar belirgin farklar olmadığı görülmektedir. Estonya, Finlandiya, Litvanya ve Slovenya gibi ülkelerde ise kadınların puanları erkeklerden daha yüksektir (UNECE, 2014: 34). Yıllar içindeki dağılıma bakıldığında ise hemen hemen her ülkenin her geçen yılda gelişme gösterdiği görülür. Bileşenler arasında en önemli gelişim ise yaşlıların bilişim teknolojileri kullanımında gerçekleşmiştir (2010'da \% 26, 2014 yılında \% 41) (UNECE, 2015).

Türkiye özelinde değerlendirme yapıldığında ise Aktif Yaşlanma için Kapasite ve Elverişli Ortam parametresine göre 44.6 puanla Türkiye'nin listenin sonunda yer aldığı görülür. Her ne kadar mental iyilik halinde, eğitim seviyesinde ve bilişim teknolojileri kullanımında yıllar içinde olumlu yönde bir gelişim 
olsa da yine de $\mathrm{AB}$ ortalamasına ulaşılamamaktadır. Türkiye'de yaşlıların $\% 48$ 'i duygusal olarak kendilerini iyi hissettiklerini beyan ederken yalnızca \%8'i her hafta internet kullandıklarını ifade etmişlerdir. Buna karşılık yaşlıların yalnızca \%14'ü lise ve üzeri bir eğitime sahiptir. Yaşam beklentisi açısında da Türkiye'de kadınlar ve erkekler arasında belirgin farklar bulunmaktadır. Türkiye'de erkekler $\mathrm{AB}$ ortalamasının da üzerinde sağlıklı yaşam beklentisine sahiptir. $\mathrm{Bu}$ durum, kadınlarda sağlık sorunları nedeniyle günlük aktivitelerde erkeklere göre daha yüksek sınırlamalara işaret etmektedir. Kadınların erkeklere kıyasla çok geride oldukları bir diğer bileşen de bilişim teknolojilerinin kullanımı bileşenidir. Türkiye' de yaşlı erkeklerin \%13'ü interneti en az hafta bir kez kullanırken bu oran kadınlar söz konusu olduğunda \%3'e düşmektedir. Benzer durum kadınların eğitim seviyesi için de geçerlidir. Türkiye' de yaşlı erkeklerin lise ve üzerinde mezun olma oranı $\% 20$ iken kadınlarda bu oran sadece $\% 8,5$ 'tir (UNECE, 2016: 20).

\section{Aktif Yaşlanmaya Yönelik Eleştiriler ve Türkiye için Endeks Önerileri}

Nüfusun yaşlanması karşısında oluşturulan politikalar genelde yaşlanmaya yönelik iki bakış açısı üzerine inşa edilir. Bu bakış açılarının ilki yaşlıların pasif ve bağımlı, ikincisi ise hem sosyal hem de ekonomik anlamda kaynak olduğu düşüncesinden hareket eder (Foster ve Walker, 2015: 83; Manuel de Sao Jose, 2017: 49). Örneğin Dünya Bankası'nın 1994 yılında yayınlamış olduğu Averting the Old Age Crisis (Yaşlı Nüfusun Krizinden Kaçınma) başlıklı rapor, nüfusların yaşlanmasını bir kriz olarak göstererek birinci bakış açısını seçmiş ve ülkelerin sosyal güvenlik sistemlerini gözden geçirmelerine neden olmuştur (World Bank, 1994). Rapor, yaşam süresinin tüm dünyada artmasından ve gelecekte nüfusun yaşlanmasından dolayı sağlık ve emeklilik sistemlerinin giderlerinin artmasını önlemek için öncelikle bireysel çabaların teşvik edildiğini göstermektedir. Bu bağlamda bireyin ömrü içinde sağlıklı geçirdiği yılları artırması ve bireyin çalışma hayatından erken ayrılmaması düşüncesi üzerine inşa edilen yeni yaklaşımlarının bu bakış açısının ürünü olduğu ifade edilebilir (Tunçkanat, 2011). Ancak bu noktada, Dünya Bankası'nın kriz olarak değerlendirdiği duruma çözüm olarak ikinci bakış açısını seçtiğini belirtmek gerekir. İyi yaşlanmayı odak noktasına alan bu yeni yaklaşımlar için pek çok farklı terimin kullanıldığı bilinmektedir. Başarılı yaşlanma, aktif yaşlanma, sağlıklı yaşlanma, pozitif yaşlanma, üretken yaşlanma ve yetkin yaşlanma bu yaklaşımların başında gelmektedir. Bununla birlikte pratikte, aktif yaşlanma 
politikaları, çalışma hayatının genişlemesini önceleyen üretkenci dar bir ekonomik bakış açısıyla hareket ederek ücretli istihdamda yer almayanları göz ardı etmiştir. (Foster ve Walker, 2015: 83).

Aktif yaşlanma yaklaşımına yönelik eleştiriler, aktif yaşlanmanın hareket noktası olan aktivite kuramına yönelik eleştirilerle paralellik gösterir. Aktivite kuramının en çok eleştirilen tarafı, yaşlı insana devamlı aktif insan tipini dayatmaya çalışmasıdır. Ancak bu dayatma sırasında aktiflik açısından yaşılıarın eşit şanslara sahip olmadığı göz ardı edilir. Bununla birlikte kuramın bir diğer varsayımı, genç ve orta yaşlı insanların hep aktif olduğudur. Kuram, orta yaşlı insanları yaşlı insanlardan ayıran özelliklerin aktivite ve yararlılık olduğu tezi üzerine inşa edilir. Bu bakış açısından hareketle pasiflik yararsızlığı, pasif yaşı da mutsuzluğu ifade etmektedir. Bununla birlikte aktivite kuramı, emeklilik ve yaşlılıkla birlikte ortaya çıkan sorunların kaynağını bireyin kendisinde görür. Buradaki tek istisnai durum, kişinin fiziksel yönden aktif olamayacak durumda olmasıdır. Bu zorunlu "pasiflikten” ötürü de zaten yaşlıyı mutsuz bir yaşlılık durumu bekler. Böyle bir fiziki engeli olmayan yaşlının ise emeklilikle kaybettiği kimi rolleri yeni rollerle telafi etmesi gerekir. Kişinin aktif olmayı isteyip istemediği sorgulanmaz. Kuramın eleştirilen bir diğer tezi de kişiler arasındaki ilişki kalitesinin yaşlılıkta da aynı kalması gerektiğini savunmasıdır. İlişki kalitesinin korunmasıyla kişinin kendisine ihtiyaç duyulduğu hissi korunacaktır. Ancak toplum, yaşlıyı önceki aktivitelerinden dolayı takdir edemez mi sorusu yanıtsız kalmaktadır (Tufan, 2016:147-148).

Aktif yaşlanma endeksi, yetenekleri değil de mevcut kazanımları ölçtüğü için politika oluşturma amaçları bağlamında değerli ama eksik bir araç olarak yorumlanmakta ve eleştirilmektedir. Her ne kadar AAI, yaşlı bireylerin potansiyellerini açığa çıkarma hedefini ortaya koymuş olsa da endeks, yetenekleri veya potansiyel başarıları değil, yalnızca başarıları (diğer bir ifadeyle uygulamaları ve faaliyetleri) ölçmektedir (Manuel de Sao Jose vd., 2017). Bu eleştiriye Romanya örneğini vererek açıklık getiren Manuel de Sao Jose ve arkadaşları (2017), AAI sonuçlarına göre Romanya'nın yaşlı istihdam oranının \% 51,8 olduğunu ancak bu sonucun, bu kişilerin istihdam edilmeye ne kadar değer verdiğini veya bunun ne kadarının bir zorunluluk değil de bir seçime dayandığını göstermediğini vurgulamaktadırlar. Bu durumun bilinmemesi durumunda da, eğer Romanya'daki yaşlı bireyler düşük emekli gelirleri nedeniyle çalışmak zorunda kalıyor ve aslında çalışmak istemiyorlarsa 
politika yapıcılar için istihdamın teşvik edilmesi doğru bir çıkarım olmayacaktır. Bununla birlikte Manuel de Sao Jose ve arkadaşlarına (2017) göre, DSÖ’nün tanımı üzerinden gidildiğinde aktif yaşlanmaya ait temel özelliklerden (1-Aktif yaşlanma, bireysel bir sorumluluktan ziyade toplumsal bir sorumluluk olarak algılanır; 2-Aktif yaşlanma, yaşlıların ihtiyaçlarına, isteklerine ve kapasitelerine saygı duymalıdır; 3-Aktif yaşlanma, zayıf, engelli ve bakıma muhtaç yaşlı insanlar tarafından da ulaşılabilir olmalıdır; 4-Aktif yaşlanma fiziksel ve zihinsel, üretken ve üretken olmayan çoklu aktivitelerden oluşur; 5-Aktif yaşlanma yaşam boyunca gerçekleşen bir süreçtir (yaşam boyu perspektifi); 6-Aktif yaşlanmanın nihai amacı, yaşlıların yaşam kalitesini arttırmaktır; 7-Aktif yaşlanma çeşitli faktörlerle (ekonomik, sosyal, politik vb.) şekillenir) sadece dördüncüsüne (fiziksel ve zihinsel, üretken ve üretken olmayan çoklu aktivitelerden oluşur) yer vermiştir. Bununla birlikte aktif yaşlanma yaklaşımı, bireysel eylemlere ("katılan" ve "meşgul olan" yaşlı insanlara) daha çok vurgu yapmakta ve özellikle sağlıksız, bağımlı ve güvensiz yaşam durumlarını dışlamaktadır. Özetle, nüfusun yaşlanmasına ait sorunlara "one size fits all (tek beden herkese uyar)" çözümünün teşvik edilmesi, "aktif/başarılı yaşlılar” ve "pasif/başarısız yaşlılar" olmak üzere iki yaşlı sınıfın oluşmasını beraberinde getirebilir ki bu durum sosyal eşitsizliklerin daha da artmasının neden olur. Manuel de Sao Jose ve arkadaşları, aktif yaşlanma endeksini eleştirirken hareket noktası olarak Virpi Timonen'nin 2016 yılında aktif yaşlanmaya alternatif olarak yazmış olduğu Başarılı ve Aktif Yaşlanmanın Ötesi: Model Yaşlanma Teorisi (Beyond Successful and Active Ageing: A Theory of Model Ageing) adlı eserini kullanmışlardır. Timonen aktif yaşlanma kuramını bütün yaşlıları homojen bir grup olarak değerlendirmesi bakımından eleştirmektedir. Timonen'e göre yalnızca araştırmacılar değil, politika yapıcılar ve piyasa da yaşlıların cinsiyetini, cinsel yönelimlerini, sosyal sınıflarını ve etnik gruplarını göz ardı etmektedirler. Bu heterojenliği göz ardı ettikleri için de gerek politika yapıcılar gerekse piyasa, herkese uygulanabilecek tek bir model oluşturur ve bunu her yaşlıya dayatırlar. Bu bakış açısından hareketle Timonen yaşlıları başarılı ve aktif yaşlanma konseptine göre yaşayan "model" yaşlılar ve bir şekilde bu konseptten sapan "model olmayan, anti model" yaşlılar olmak üzere ikiye ayırır (Tadic, 2018). Timonen'e göre yaşlılar, potansiyel olarak neden olabilecekleri "sorunlara" bir çözüm olarak algılanırlar. Bu kapsamda yaşlıların, serbest piyasada kalmaya teşvik edilmesi ve diğer yaşlı insanlara ve çocuklara bakmaları, "problemi çözüme dönüştürmek" yaklaşımının örnekleri arasında 
sayılabilir. Aktif yaşlanma yaklaşımına göre örneğin yaşlı birey sağlıklı ve işgücü piyasasında kalarak ve toplum yararına gönüllü, ücretsiz aktivitelerde bulunarak kişisel sorumluluklarını üstlenen "aktif yaşlı" olmak durumundadır. Dolayısıyla da nüfusun yaşlanması sorununa yönelik çözümler giderek daha az kolektif olmakta buna karşılık daha çok bireysellik taşımaktadır. Buradan hareketle Timonen'e göre "tek beden herkese uyar" yaklaşımından (örneğin aktif yaşl1) uzaklaşıp, yaşlılığın heterojen yapısını göz önünde bulundurmak gerekir (Manuel de Sao Jose vd., 2017: 50). Bu heterejon yapı yalnızca yaş1ı bireyler için değil ülkeler için de söz konusudur. Bu açıdan bakıldığında da niteliksel olarak çok farklı olan ülkelerin eşit özelliklere sahiplermiş gibi sıralanması aktif yaşlanma endeksine yöneltilen bir diğer eleştiri olarak karşımıza çıkmaktadır (Amado vd., 2016). Ülkelerin kendilerine has özelliklerinin bulunması, ekonomik, kültürel, sosyal ve politik farkl1lıklarının olması Avrupa'nın heterojen yapısını göstermekte ve bu tarz bir sıralamanın niteliğini zayıflatmaktadır. Bununla birlikte aktif yaşlanmaya ilişkin beklentiler, yaşlıların deneyimlerine uygun olmayan, orta yaşı ya da genç bakış açısına göre etkinlik tanımlama eğiliminde olan politika yapıcılar ve araştırmacılar tarafından belirlendiği için de eleştirilmekte (Reed vd., 2003), politika oluşturma süreçlerine yaşlıların kendilerinin de dahil edilmesi gerektiği vurgulanmaktadır (Foster ve Walker, 2015).

Aktif yaşlanma modeline alternatif olması bakımından Timonen'in model yaşlanma teorisi tek değildir. Örneğin, Aldwin ve Gilmer (2004) tarafından geliştirilen optimal yaşlanma modeli, kişinin kaynaklarına, sağlık durumuna ve yaptıkları seçimlere bağlı olarak iyi bir şekilde yaşlanmanın farklı yolları olabileceğini savunur. Benzer şekilde, Liang ve Luo (2012) tarafından geliştirilen uyumlu yaşlanma modeli, Yin-Yang felsefesine dayanır ve yaşlanmayı, Timonen'in başarılı yaşlanmanın homojenliği eleştirisine bağlayan, tekdüzelikten ziyade farklılıkları temel alan bir denge olarak değerlendirir. Uyum, denklik yerine farklılıklara dayalı dengeyi ifade eder. Bu yeni söylem, yaşlılığın zorluklarını ve firsatlarını tanımayı, aktivite ve ayrılma teorileri arasındaki gerilimi azaltmayı, beden ve zihin bütünlüğünü iyileştirmeyi ve insanların birbirine bağlı doğasını vurgulamayı amaçlamaktadır.

Görüldüğü üzere aktif yaşlanma yaklaşımına eleştiriler, temelde yaşlılığın homojen olarak algılanmasına ve aktifliğin istihdam edilebilirlikle eş değermiş gibi görülmesine yöneliktir. Bu noktada da her ne kadar endeks, pek çok farklı 
parametrede ülkeleri kıyaslama imkanı sunması bakımından olumlu özellikler barındırsa da ülkelerin kendilerine has özelliklerini yok sayması açısından eksiklikler barındırmaktadır. Özellikle de bir pilot çalışma dahi olsa, toplumsal ve kültürel anlamda çok farklı bir yapıya sahip olan Türkiye'nin bu sıralamaya dahil edilmesi, değerlendirmenin ne kadar doğru yorumlanabileceği sorusunu beraberinde getirmektedir. Kuşkusuz mevcut veriler ve nüfus projeksiyonları, Türkiye'nin çok hızlı yaşlanıyor olduğunu, dolayısıyla da bu konu üzerinde ivedilikle politika üretilmesi gerektiğini ortaya koymaktadır. Nitekim Türkiye'de nüfusun yaşlanması sorununa ilişkin kimi araştırmaların yapıldığı ve aynı zamanda kimi sivil toplum kuruluşunun bu konu hakkında çalıştıkları bilinmektedir. Emine Özmete (2016) yürütücülüğünde yapılan Türkiye Aktif ve Sağlıklı Yaşlanma Araştırması ve İsmail Tufan'ın 2000 yılında başlatmış olduğu Geroatlas isimli Türkiye'de yaşlılığın ve yaşlanmanın ampirik araştırma serisi bu araştırmalara örnek olarak verilebilir. Bunun yanı sıra son yıllarda Türkiye'de yaşlanma alanında faaliyet gösteren derneklerin, vakıfların, araştırma ve uygulama merkezlerinin sayısının gittikçe arttığı gözlemlenmektedir. Türk Geriatri Vakfı, Yaşlılık Araştırmaları Merkezi, Yaşılı Hakları Derneği, Yaşlılarla Dayanışma Derneği, Yaşı ı Sorunları Araştırma Derneği gibi pek çok dernek ve vakfın bu alanda çalıştığı görülmektedir. Bununla birlikte kalkınma planlarında yaşlılara yönelik politikalara yer verildiği, 2007 yılında Başbakanlık Sosyal Hizmetler ve Çocuk Esirgeme Kurumu'nun koordinatörlüğünde, “Türkiye'de yaşlıların durumu ve yaşlanma ulusal eylem planı” için bir çalıştay gerçekleştirildiği, Sağlık Bakanlığı'nca 2015-2020 yıllarını kapsamak üzere Türkiye Sağlıklı Yaşlanma Eylem Planının hazırlandığı ve son olarak da 20-22 Şubat 2019 tarihleri arasında I. Yaşlılık Şurası'nın düzenlendiği bilinmektedir. Ancak yine de Türkiye'deki yaşlılara yönelik politikaların genel özelliğinin yaşlıyı vatandaş olarak ve yaşlılığa bağlı risklerin giderilmesini bir vatandaş hakkı olarak görmediği ifade edilmelidir (Korkmaz, 2014: 210). Çünkü, Türkiye' de halen daha aile, devlet ve vatandaş arasında tampon mekanizma görevi üstlenmektedir (Buğra, 2008). Çalışmanın kapsamını aşması bakımından Türkiye'de yaşlı politikalarına girilmeyecektir. Bu noktada hedeflenen, mevcut durum tespitinin yapılabilmesi ve tüm eleştirilebilir yanlarına rağmen kıyaslama firsatı ve mevcut durum tespiti sunduğu için aktif yaşlanma endeksi benzer endekslerin Türkiye'de de uygulanmasının önerilmesidir. Ancak bu noktada kimi eleştiriler ve öneriler gerekmektedir. Öncelikle aktif yaşlanma endeksinin birebir uygulanması Türkiye'nin Avrupa ülkelerinden farklı olarak kendine 
özgü sosyokültürel özelliklerinden dolayı doğru görünmemektedir. Örneğin aktif yaşlanma endeksinin istihdam parametresi için bireye yalnıza ücretli bir işte çalışıp çalışmadığının ötesinde hangi şartlarda ve ne amaçla çalıştı̆̆ sorulmalıdır. Bu bağlamda çalışmanın bir zorunluluk olup olmadığı mutlaka ayrı değerlendirilmelidir. Bir diğer ayrıştırılması gereken soru ise çocuk/torun bakımını içeren sorudur. Sosyal katılım parametresinin bir bileşeni olan çocuk/ torun bakımı mutlaka ayrı ayrı sorulmalıdır. Bununla birlikte tıpkı istihdam parametresinde olduğu gibi, bu bakım görevinin de yerine getirilmesinin bir zorunluluk olup olmadığı sorulmalıdır. Bir diğer önerisi ise yoksulluğun ölçüldügü parametrenin ağırlığının artırılması ile ilgilidir. Nitekim sağlık durumunu belirleyen asıl unsur yaş değil yoksulluk ve toplumsal cinsiyettir.

\section{Sonuç}

Ülkelerinin demografilerinin yüksek doğurganlık ve ölüm oranlarından, düşük doğurganlık ve ölüm oranlarına doğru bir seyir alacağını ifade eden demografik dönüşüm kuramı, bütün toplumların kaçınılmaz olarak bu aşamalardan geçeceğini iddia eder. Nitekim 20. yüzyıl boyunca Kıta Avrupası, yaşlanan toplumlarının dönüşümüne tanıklık ederken, bugün de Türkiye, demografik dönüşümün son aşamasına gelerek hızla yaşanan nüfusuna tanıklık etmektedir. Toplumun yaşlanması kuşkusuz yalnızca Türkiye’ye özgü bir durum değildir. Özellikle demografik dönüşümünü tamamlamış Avrupa ülkeleri, Türkiye'nin gelecekte yüzleşmek zorunda kalacağı sorunlarla baş etmiş olmaları bakımından önemli rol modeller olabilmektedir. Bununla birlikte DSÖ, BM gibi uluslararası kuruluşların bu sorunların çözümü adına hem mikro hem de makro bir bakış açısından hareketle aktif yaşlanmayı destekledikleri görülmektedir. Aktif yaşlanma yaklaşımı, insanların yaşamları boyunca fiziksel, sosyal ve bilişsel iyi olma potansiyellerini gerçekleştirmelerine (mikro bakış) yardımcı olurken, ihtiyaç duyduklarında yeterli koruma, güvenlik ve bakımın sağlanmasına (makro bakış) işaret eder. Bu noktada yaklaşımın kazan kazan yaklaşımı benimsediği ifade edilmelidir. Yaklaşım, bir yandan sağlık ve sosyal giderlerin düşmesini sağlamaları bakımından yaşlı bireylerin topluma ve politik yaşama dahil olmasını, emeklilik giderlerinin düşmesi için de istihdam edilebirliklerinin artırılmasını, bununla birlikte bu kriterleri yerine getiren bireyin öznel iyi oluşunu destekleyeceğini savunmaktadır. Daha basit bir ifadeyle aktif yaşlanma ile birey hem kendini daha sağlıklı ve mutlu hissetmekte hem de sosyal güvenlik açısından devletine yük olmamaktadır. Sosyal güvenliğin 
bir hak olduğu unutulmadan, aktif yaşlanmanın bir hedef olmasında sakınca yoktur. Buradan hareketle yaşlanmanın neden olacağ 1 toplumsal ve ekonomik sorunlara çözüm önerisi sunması bakımından oluşturulan aktif yaşlanma endeksi, mevcut durumun tespiti açısından önemlidir. Bu bağlamda da dünyanın hızlı yaşlanan ülkelerinden biri olarak Türkiye'nin yaşadığı bu hızlı dönüşüme adapte olması, sosyal ve ekonomi politikalarını gözden geçirmesi ve bir an önce harekete geçmesi gerekmektedir. Bu noktada öncelikli hareket noktası, Türkiye'nin çok hızlı yaşlandığını ve halihazırda da yaşı bir ülke olduğu gerçeğini kabul etmesi olmalıdır [Birleşmiş Milletler (BM) için yaşlı ülke olma alt sınır, yaşlı nüfus oranının \% 8'in üstü olmasıdır]. Bu kabulün ardından da aktif yaşlanma endeksi benzeri bir endeksin Türkiye'de de düzenli aralıklarla yapılması önerilmektedir. Ancak bu noktada aktif yaşlanma endeksinin birebir aynısının uygulanması Türkiye'nin kendine has koşulları, sosyo-kültürel yapısı bakımından doğru görülmemektedir. Bu bağlamda öncelikle yapılması gereken halihazırda yaşlı bir ülke olduğumuz gerçeğinin kabulüyle, bu ve benzeri yaşılıarı merkeze alan çalışmaları artırmaktır. Özellikle yaşlılığa yönelik boylamsal araştırmalar yapmak ve yaşlılara yönelik politikaları bu verilere dayanarak oluşturmaktır.

\footnotetext{
Hakem Değerlendirmesi: Dış bağımsız.

Çıkar Çatışması: Yazar çıkar çatışması bildirmemiştir.

Finansal Destek: Yazar bu çalışma için finansal destek almadığını beyan etmiştir.

Peer-review: Externally peer-reviewed.

Conflict of Interest: The author has no conflict of interest to declare.

Grant Support: The author declared that this study has received no financial support.
} 


\section{Kaynakça/References}

Alcock, Pete, Marharet May ve Karen Rowlingson, K. (2011). Sosyal Politika Kuramlar ve Uygulamalar. (Ed. Bülent Özçelik), Ankara: Siyasal Kitabevi.

Aldwin, Carolyn M. ve Diana Fox Gilmer (2004). Helath, Illness and Optimal Aging, Biological and Psychosocial Perspective, Second Edition, Springer Publishing Company, New York.

Amado, C. A. F., São José, J. M., ve Santos, S. P. (2016). Measuring active ageing: A Data En- velopment Analysis approach. European Journal of Operational Research, $000,1-17$.

Butler RN (2002). The study of productive aging. Journal of Gerontology, Series B: Psychological Sciences and Social Sciences. 57B:323. doi: 10.1093/ geronb/57.6.S323.

Buğra, Ayşe (2008). Kapitalizm, Yoksulluk ve Türkiye’de Sosyal Politika, İletişim Yayınları, İstanbul.

Collins, N. (2014). A brief introduction to the Social theory of Ageing and Ageism. Old Age Psychiatrist, 59, s.1-3.

Duben, Alan (2018). "Türkiye ve Avrupa'da Nüfus Yaşlanması, Aile, Piyasa ve Devlet", Yaşlanma ve Yaşlılık içinde (der. Alan Duben), İstanbul Bilgi Üniversitesi Yayınları, s.67-79.

European Commission (EC). (1999). Towards a Europe for all ages. - Promoting Prosperity and Intergenerational Solidarity, Brussels: Author. COM(1999) 221 final

Fernandez-Ballesteros, R.; Robine, J.M.; Walker, A.; Kalache, (2013). A. Active aging: A global goal. Curr. Gerontol. Geriatr. Res. doi:10.1155/2013/298012.

Foster, L. and Walker, A. (2015). Active and successful aging: a European policy perspective., Gerontologist. 2015, 55(1), 83-90. doi: 10.1093/geront/gnu028.

Fung, Helrnr H. (2013). Aging in Culture, The Gerontologist, 53(3), 369-377

doi:10.1093/geront/gnt024

Hablemitoğlu, Şengül ve Özmete, Emine (2010), Yaşlı Refah. Kilit Yayınları.

Hablemitoğlu, Şengül (2016). "Yaşlanmanın "Kadınlaşması”, Yaşlılık Sosyolojisi içinde (ed. Harun Ceylan), Nobel, Ankara, s. 119-137.

Kalkınma Bakanlığı (2014), Yaşlanma Özel İhtisas Komisyon Raporu, ISBN 978-6059041-00-3 Yayın No: KB: 2900 - ÖİK: 740, Ankara

Kinsella, K. ve Phillips, D. R. (2005), "Global Aging: The Challenge of Success", Population Bulletin, Vol. 60, No.1, Washington D.C.

Kinsella, K.ve, He, W. (2009). An Aging World: 2008, U.S. CensusBureau, International Population Reports, Washington, DC, Government Printing Office, P95/09-1.

Kinsella, Kevin and Yvonne J. Gist (1995), “Older Workers, Retirement, and Pension”, $A$ Comparative International Chartbook, IPC/95-2, U.S. Census Bureau,

Koç, İ., Eryurt, M. A., Adalı T. ve Seçkiner, P. (2010), Türkiye’nin Demografik Dönüşümü, Hacettepe Üniversitesi Nüfus Etütleri Enstitüsü, Ankara. 
Korkmaz, Nilüfer (2014). Türkiye'de Yaşlılık ve Sosyal Politika -Yaşlılık Politikadan Ayrı Düşünülebilir mi?, Küreselleşme ve Yaşlılık Eleştirel Gerontolojiye Giriş içinde (der. Nilüfer Korkmaz ve Suzan Yazıcı), Ütopya Yayınevi, Ankara, s 189-215.

Liang, Jaylene ve Baozhen Luo (2012). "Toward a discourse shift in social gerontology: From successful aging to harmonious aging”, Journal of Aging Studies 26(3):327-334

Manuel de Sao Jose, Jose, Virpi Timonen, Carla Alexandra Filipe Amado ve Sergio Pereira Santos (2017). A Critique of the Active Ageing Index, Journal of Aging Studies, Say1 40, ss 49-56.

Mendes, Felismina Rosa (2013). Active Ageing: A Right or A Duty?, Health Sociology Review, Volume 22, Issue 2, p. 174-185.

Özmete, Emine (2016). Türkiye Aktif ve Sağlıklı Yaşlanma Araştırması. T.C. Sağlık Bakanlığı Sağlığın Geliştirilmesi Genel Müdürlüğü. Ankara.

Reed J., Cook G., Childs S., Hall A. (2003). “Getting Old is not for Cowards: Comfortable, Healthy Ageing” York: Joseph Rowntree Foundation.

Schroots, J. J. (1996). "Theoretical Developments in the Psychology of Aging", The Gerontologist, Vol 36, No 6, s. 742-748.

Tadic, Dora (2018). Virpi Timonen (2016). Beyond Successful and Active Ageing: A Theory of Model Ageing. Bristol, UK: Policy Press, 119 pp. ISBN 9781447330172 (hardback), International Journal of Ageing and Later Life, 11(2), 87-90.

Tufan, İsmail (2016). Antik Çăg'dan Günümüze Yaşlılık ve Yaşlanma, Nobel Yayınları, Ankara.

Tunçkanat, Figen (2011). “Avrupa Birliğgi’nin Yaşlı Refahı ve Yaşlılığa İlişkin Politikaları”, Yaşlılar için Sosyal Politika Gündemi Konferansı Kitabı, Ankara Üniversitesi Yaşlılık Çalışmaları Uygulama ve Araştırma Merkezi, Ankara.

TÜSİAD (1999), Türkiye’nin Fırsat Penceresi Demografik Dönüşüm ve İzdüşümleri, yayın No: TÜSİAD-T/99-1-251

UNECE (2014). AAI 2014, Active Ageing Index for 28 European Union Countries, November.

UNECE (2016), The Active Ageing Index Pilot Studies For Serbia and Turkey, UNECE Population Unit

UNECE (2013), Active Ageing Index 2012 Concept, Methodology and Final Results, UNECE Grant No: ECE/GC/2012/003

UNECE/ European Commission (2015). "Active Ageing Index 2014: Analytical Report", Report prepared by Asghar Zaidi of Centre for Research on Ageing, University of Southampton and David Stanton, under contract with United Nations Economic Commission for Europe (Geneva), co-funded by European Commission's Directorate General for Employment, Social Affairs and Inclusion (Brussels).

United Nations (2015). Department of Economic and Social Affairs, Population Division World Population Ageing 2015 (ST/ESA/SER.A/390).

UNECE / European Commission (2019). “2018 Active Ageing Index: Analytical 
Report”, Report prepared by Giovanni Lamura and Andrea Principi under contract with the United Nations Economic Commission for Europe (Geneva), co-funded by the European Commission's Directorate General for Employment, Social Affairs and Inclusion (Brussels).

United Nations, Department of Economic and Social Affairs, Population Division (2019). World Population Prospects 2019: Highlights (ST/ESA/SER.A/423).

Uyanık, Y. (2017). "Yaşlılık, Yaşlanan Nüfus ve Sosyal Politika", İş ve Hayat Dergisi, Say1 5, s. 67-101.

WHO (2015). What is “Active Ageing”?, http://www.who.int/ageing/active_ageing/en/ erişim tarihi: 6/7/2015

World Bank (1994). Averting the Old Age Crisis, Polices to Protect the Old and Promote Growth, Oxford University Press, New York.

WHO (2002). Active ageing: A policy frame- work (Report No. WHO/NMH/NPH/02.8). Geneva, Switzerland: Author.

WHO (2019). World health statistics 2019: Monitoring health for the SDGs, sustainable development goals. Geneva:. Licence: CC BY-NC-SA 3.0 IGO.

Zaidi, A., Gasior, K., Hofmarcher, M. M., Lelkes, O., Marin, B., Rodrigues, R., et al. (2013). Active ageing index 2012: Concept, methodology and nal results. European Centre Vienna.

Zaidi, Asghar (2015). “Active Ageing Index 2014”, Active Ageing Index Project Presentation at the Expert Group Meeting on Ageing, New York, 7-9 July. 
